\title{
The impact of monthly variation of the Pacific-North America (PNA) teleconnection pattern on wintertime surface-layer aerosol concentrations in the United States
}

\author{
Jin Feng ${ }^{1,2}$, Hong $\mathbf{L i a o}^{3}$, and Jianping $\mathbf{L i}^{4,5}$ \\ ${ }^{1}$ State Key Laboratory of Atmospheric Boundary Layer Physics and Atmospheric Chemistry, Institute of Atmospheric \\ Physics, Chinese Academy of Sciences, Beijing, China \\ ${ }^{2}$ University of Chinese Academy of Sciences, Beijing, China \\ ${ }^{3}$ School of Environmental Science and Engineering, Nanjing University of Information Science \& Technology, \\ Nanjing, China \\ ${ }^{4}$ College of Global Change and Earth System Science, Beijing Normal University, Beijing, China \\ ${ }^{5}$ Joint Center for Global Change Studies, Beijing, China
}

Correspondence to: Hong Liao (hongliao@ nuist.edu.cn)

Received: 13 October 2015 - Published in Atmos. Chem. Phys. Discuss.: 25 November 2015

Revised: 28 March 2016 - Accepted: 29 March 2016 - Published: 21 April 2016

\begin{abstract}
The Pacific-North America teleconnection (PNA) is the leading general circulation pattern in the troposphere over the region of North Pacific to North America during wintertime. This study examined the impacts of monthly variations of the PNA phase (positive or negative phase) on wintertime surface-layer aerosol concentrations in the United States (US) by analyzing observations during 1999-2013 from the Air Quality System of the Environmental Protection Agency (EPA-AQS) and the model results for 1986-2006 from the global three-dimensional Goddard Earth Observing System (GEOS) chemical transport model (GEOS-Chem). The composite analyses on the EPAAQS observations over 1999-2013 showed that the average concentrations of $\mathrm{PM}_{2.5}$, sulfate, nitrate, ammonium, organic carbon, and black carbon aerosols over the US were higher in the PNA positive phases $(25 \%$ of the winter months examined, and this fraction of months had the highest positive PNA index values) than in the PNA negative phases $(25 \%$ of the winter months examined, and this fraction of months had the highest negative PNA index values) by $1.0 \mu \mathrm{g} \mathrm{m}^{-3}(8.7 \%), 0.01 \mu \mathrm{g} \mathrm{m}^{-3}(0.5 \%), 0.3 \mu \mathrm{g} \mathrm{m}^{-3}$ (29.1\%), $0.1 \mu \mathrm{g} \mathrm{m}^{-3}(11.9 \%), 0.6 \mu \mathrm{g} \mathrm{m}^{-3}(13.5 \%)$, and $0.2 \mu \mathrm{g} \mathrm{m}^{-3}(27.8 \%)$, respectively. The simulated geographical patterns of the differences in concentrations of all aerosol species between the PNA positive and negative phases were similar to observations. Based on the GEOS-Chem simula-
\end{abstract}

tion, the pattern correlation coefficients were calculated to show the impacts of PNA-induced variations in meteorological fields on aerosol concentrations. The PNA phase was found (i) to influence sulfate concentrations mainly through changes in planetary boundary layer height (PBLH), precipitation (PR), and temperature; (ii) to influence nitrate concentrations mainly through changes in temperature; and (iii) to influence concentrations of ammonium, organic carbon, and black carbon mainly through changes in PR and PBLH. Results from this work have important implications for the understanding and prediction of air quality in the US.

\section{Introduction}

Aerosols are the major air pollutants that have adverse effects on human health, reduce atmospheric visibility, and influence climate through aerosol-radiation and aerosol-cloud interactions (IPCC, 2013). Aerosol concentrations are high over the industrialized regions such as the United States (US), Europe, and East Asia, which are driven by emissions of aerosols and aerosol precursors (Dutkiewicz et al., 2000; Vestreng et al., 2007; Hand et al., 2012a; Mijling et al., 2013) and regional meteorological conditions. 
Previous studies have shown that aerosol concentrations are very sensitive to meteorological parameters (Aw and Kleeman, 2003; Wise and Comrie, 2005; Dawson et al., 2007; Kleeman, 2008; Jacob and Winner, 2009; Tai et al., 2010, 2012a; Allen et al., 2015; Markakis et al., 2015; Megaritis et al., 2014; Porter et al., 2015). Aw and Kleeman (2003) examined the sensitivity of $\mathrm{PM}_{2.5}$ (aerosol particles with a diameter $\leq 2.5 \mu \mathrm{m}$ ) concentration to temperature by performing sensitivity studies in the California Institute of Technology/UC Davis (CIT/UCD) air quality model. A cross-board increase in temperature by $5 \mathrm{~K}$ in southern California on 25 September 1996, led to decreases in peak $\mathrm{PM}_{2.5}$ concentrations by up to $30.7 \mu \mathrm{g} \mathrm{m}^{-3}(\sim 30 \%)$. Wise and Comrie (2005) reported, by statistical analyses of observational data sets obtained from Air Quality System of the US Environmental Protection Agency (EPA-AQS), that the variations in meteorological parameters accounted for 20$50 \%$ of the variability in aerosol levels over 1990-2003 in five metropolitan areas in the southwestern US. They found that aerosols in these five cities were most sensitive to relative humidity. Dawson et al. (2007) found, by sensitivity studies in the Particulate Matter Comprehensive Air Quality Model with extensions (PMCAMx), that $\mathrm{PM}_{2.5}$ concentrations in summer had a small sensitivity to temperature increases $\left(-16 \mathrm{ng} \mathrm{m}^{-3} \mathrm{~K}^{-1}\right.$ on average) because the increases in sulfate offset the decreases in nitrate and organics, while $\mathrm{PM}_{2.5}$ concentrations in winter decreased significantly with temperature $\left(-170 \mathrm{ng} \mathrm{m}^{-3} \mathrm{~K}^{-1}\right.$ on average) because the increases in temperature led to large reductions in nitrate and organics. Dawson et al. (2007) also showed that $\mathrm{PM}_{2.5}$ concentrations increased with humidity in both winter and summer. Jacob and Winner (2009) summarized through literature review that the regional stagnation, mixing depth, and precipitation are the most important meteorological parameters that influence surface-layer aerosol concentrations. Future climate change was also simulated to influence aerosol levels over the US by -1 to $+1 \mu \mathrm{g} \mathrm{m}^{-3}$ (Jacob and Winner 2009), as a result of the climate-induced changes in atmospheric oxidants, transport, deposition, and the shift of gas-particle equilibria (Liao et al., 2006; Unger et al., 2006; Bauer et al., 2007; Jacob and Winner, 2009; Pye et al., 2009; Lam et al., 2011; Day and Pandis, 2011; Juda-Rezler et al., 2012; Tai et al., 2012b).

Previous studies have also reported that the changes in atmospheric circulation pattern and climate systems, such as the East Asian summer monsoon (EASM), North Atlantic Oscillation (NAO), El Niño-South Oscillation (ENSO), Atlantic Multidecadal Oscillation (AMO), and Arctic sea ice (ASI), can modulate distributions and concentrations of aerosols (Moulin et al., 1997; Singh and Palazoglu, 2012; Zhu et al., 2012; Jerez et al., 2013; Liu et al., 2013; Xiao et al., 2014; Wang et al., 2015). Zhu et al. (2012) found, by simulation of aerosol concentrations over years 1986-2006 with the global chemical transport model GEOS-Chem, that the decadal-scale weakening of the EASM led to increases in aerosol concentrations in eastern China, and summertime surface aerosol concentrations in the weakest EASM years were larger than those in the strongest EASM years by approximately $20 \%$. Moulin et al. (1997) showed that the variations in NAO could influence mineral dust aerosol transported to the North Atlantic Ocean and the Mediterranean Sea, since the mean aerosol optical depth (AOD) of dust in summer correlated with the NAO index during 1983-1994 with the correlation coefficients of 0.49 and 0.66 , respectively. Jerez et al. (2013) found, by simulations of aerosols for years 1970-1999 with the CHIMERE chemistry transport model driven by the European Centre for Medium-Range Weather Forecasts Reanalysis data (ECMWF ERA-40), that the concentrations of $\mathrm{PM}_{10}$ and $\mathrm{PM}_{2.5}$ in European differed by 10 and $20 \mu \mathrm{g} \mathrm{m}^{-3}$, respectively, between the positive and negative NAO phases. By using the multi-angle imaging spectroradiometer satellite (MISR) data sets of AOD during 2000-2011, Liu et al. (2013) found a period of 3-4 years in observed summertime AOD over the North China Plain (NCP), and the peak of summertime AOD in NCP occurred 4 months later after the rapidly transition of El Niño from a warm phase to a cold phase because of the associated cyclone anomaly and maritime inflow over the NCP. Singh and Palazoglu (2012) found correlations between Pacific Decadal Oscillation (PDO) and ENSO and the aerosol exceedance days (defined as the days with $\mathrm{PM}_{2.5}$ concentrations larger than the US National Ambient Air Quality Standard) at 6 regions in the US by using the EPA-AQS $\mathrm{PM}_{2.5}$ wintertime data sets during 1950-2008.

The Pacific-North America teleconnection pattern (PNA) is one of the most recognized, influential climate patterns in the mid-latitudes over the region of North Pacific to North America during wintertime with monthly variations (Wallace and Gutzler, 1981; Blackmon et al., 1984; Liang et al., 2005; Athanasiadis and Ambaum, 2009). The PNA phase is defined by the geopotential height anomalies in the middle troposphere over the vicinity of Hawaii, the south of the Aleutian Islands, the intermountain region of North America, and the Gulf Coast region in the US (Wallace and Gutzler, 1981). A positive (negative) PNA phase is characterized by positive (negative) geopotential height anomalies over the vicinity of Hawaii and the northwestern North America, whereas it is characterized by negative (positive) geopotential height anomalies over south of the Aleutian Islands and the Gulf Coast region (see Fig. S1 in the Supplement).

The PNA has large impacts on surface-layer meteorological variables in the US during wintertime. Previous studies have reported a strong positive (negative) correlation between PNA and surface ambient temperature in the northwestern (southeastern) US (Leathers et al., 1991; Redmond and Koch, 1991; Liu et al., 2015), and a negative correlation between PNA and precipitation rate (Leathers et al., 1991; Coleman and Rogers, 2003; Ning and Bradley, 2014, 2015) and moisture (Coleman and Rogers, 2003) in the contiguous Ohio River Valley. These variations in meteorological 
parameters in the US are associated with the PNA-induced anomalies in jet stream position, activities of cold fronts, and synoptic cyclones (Leathers et al., 1991; Notaro et al., 2006; Myoung and Deng, 2009).

Several studies have examined the impacts of PNA on aerosols. Gong et al. (2006) studied the interannual variations in the trans-Pacific transport of Asian dust during 19602003 by using the northern aerosol regional climate model (NARCM). They found a negative correlation (with a correlation coefficient of -0.55 ) between the PNA and the ratio of dust mass that reached the North American continent to that exported from Asia because of the strong westerly jet in the East Pacific during the negative PNA phases. Di Pierro et al. (2011), by using satellite retrieval of aerosol optical depth (AOD) from Cloud-Aerosol Lidar with Orthogonal Polarization (CALIOP), identified 11 events of Asian aerosol transport to the Arctic during 2007 to 2009, in which four events were associated with the negative PNA phases. These studies, however, were focused on the impact of PNA on the transport of aerosols due to the variations in westerly jet stream and blocking activity. Furthermore, these studies were limited to aerosols in the regions of North America and the Arctic.

We examine in this work the impacts of monthly variations in PNA phase on aerosol concentrations in the US during wintertime, by analyses of the observed aerosol concentrations during 1999-2013 from EPA-AQS and also by simulations of aerosol concentrations for years 1986-2006 using the global chemical transport model GEOS-Chem. The scientific goals of this work are (1) to quantify the differences in wintertime concentrations of sulfate $\left(\mathrm{SO}_{4}^{2-}\right)$, nitrate $\left(\mathrm{NO}_{3}^{-}\right)$, ammonium $\left(\mathrm{NH}_{4}^{+}\right)$, black carbon (BC), organic carbon (OC), and $\mathrm{PM}_{2.5}$ in the US between different PNA phases, and (2) to understand the roles of PNA-induced variations in meteorology (for example, surface air temperature, wind speed, planetary boundary layer height, precipitation, and relative humidity) in influencing the wintertime aerosol concentrations. The definition of the PNA index, the EPA-AQS observation data used in this work, and the numerical simulation with the GEOS-Chem model are described in Sect. 2. Sections 3 and 4 present the impacts of the PNA on wintertime aerosol concentrations in the US obtained from the EPAAQS observations and the GEOS-Chem simulation, respectively. The mechanisms for the impacts of PNA on aerosols are examined in Sect. 5.

\section{Data, simulation, and methodology}

\subsection{Observed aerosol concentrations}

Observed concentrations of aerosols are obtained from the EPA-AQS (http://www.epa.gov/airquality/airdata/). The EPA-AQS daily $\mathrm{PM}_{2.5}$ mass concentrations are available over 1999-2013 at about 1200 sites, and the speciated

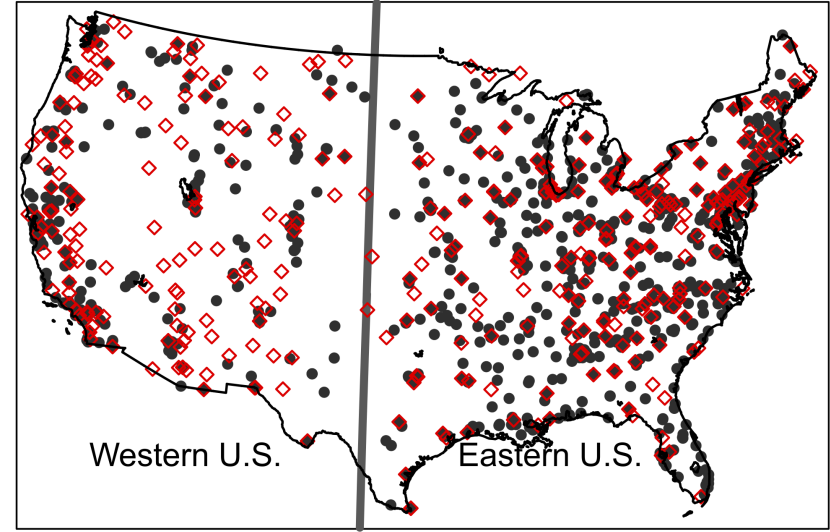

$$
\text { - } \mathrm{PM}_{2.5} \text { sites } \diamond \text { Speciation sites }
$$

Figure 1. The locations of EPA-AQS sites with measurements that meet the criteria described in Sect. 2.1 in the text. $\mathrm{PM}_{2.5}$ measurements are available for the years 1999-2013 (sites are marked by black dots) and speciated aerosol $\left(\mathrm{SO}_{4}^{2-}, \mathrm{NO}_{3}^{-}, \mathrm{NH}_{4}^{+}, \mathrm{BC}\right.$, and OC) concentrations are available over years of 2000-2013 (sites are marked by red diamonds). The grey solid line defines the western US (west of $100^{\circ} \mathrm{W}$ ) and eastern US (east of $100^{\circ} \mathrm{W}$ ).

aerosol concentrations, including those of $\mathrm{SO}_{4}^{2-}, \mathrm{NO}_{3}^{-}$, $\mathrm{NH}_{4}^{+}$, BC, and $\mathrm{OC}$, are available for 2000-2013 at about 300 sites.

The measurements of aerosol concentrations from the EPA-AQS were carried out at various time intervals (for example, with measurements every 1, 3, or 6 days) at different sites, and there were plenty of missing values at many sites. The observed concentrations are pre-processed following the three steps: (1) For a specific site, the observations are used in our analyses if the site had at least 5 months of observations and there were at least five observation records within each month. (2) The mean seasonal cycle in aerosol concentrations in the months of November-March is removed (the aerosol concentrations without seasonal cycles are defined as $C_{i, j}^{\prime}=C_{i, j}-\frac{1}{n} \sum_{i=1}^{n} C_{i, j}$, where $C_{i, j}$ is the aerosol concentrations in month $j$ of year $i, n$ is the number of years examined). Such a deseasonality approach was used in previous studies that examined the monthly variations in mineral dust aerosol (Cakmur et al., 2001; Mahowald et al., 2003), the decreasing trends in observed $\mathrm{PM}_{2.5}$ concentrations and satellite AOD in the southeastern US over 2000-2009 (Alston et al., 2012), and the monthly variations in global AOD (Li et al., 2013). (3) Since the observed aerosol concentrations exhibited a significant decreasing trend from 1999 to present in the US due to the reductions in emissions of aerosols and aerosol precursors (Alston et al. (2012); http://www3.epa. gov/airtrends/aqtrends.html\#comparison), the long-term linear trend in concentrations is identified by the least-square fit and then removed from the wintertime observed concentrations for each site. The EPA-AQS sites with measurements that meet the criteria described in (1) are shown in Fig. 1. 


\subsection{GEOS-Chem simulation}

We also examine the impacts of PNA on simulated aerosol concentrations in the US by using the GEOSChem model (version 8-2-1; http://acmg.seas.harvard.edu/ geos). The GEOS-Chem model is a global chemical transport model driven by the assimilated meteorological fields from the Goddard Earth Observing System (GEOS) of the NASA Global Modeling and Assimilation Office (GMAO). The version of the model we use has a horizontal resolution of $2^{\circ} \times 2.5^{\circ}$ and 30 hybrid $\sigma$-pressure layers from the surface to $0.01 \mathrm{hPa}$ altitude. The model has a fully coupled simulation of tropospheric $\mathrm{O}_{3}-\mathrm{NO}_{x}-\mathrm{VOC}$ (volatile organic compound) chemistry and aerosols including $\mathrm{SO}_{4}^{2-}, \mathrm{NO}_{3}^{-}$, $\mathrm{NH}_{4}^{+}$, BC, OC (Park et al., 2003, 2004), mineral dust (Fairlie et al., 2007), and sea salt (Alexander et al., 2005). Considering the large uncertainties in chemistry schemes of secondary organic aerosol (SOA), SOA in our simulation is assumed to be the $10 \%$ carbon yield of OC from biogenic terpenes (Park et al., 2003) and $2 \%$ carbon yield of OC from biogenic isoprene (van Donkelaar et al., 2007; Mu and Liao, 2014). We mainly examine simulated anthropogenic aerosols from the GEOS-Chem simulation, since mineral dust concentrations in winter are very small (Malm et al., 2004; Zhang et al., 2013) and sea salt is not a major aerosol species in the US (Malm et al., 2004).

The model uses the advection scheme of Lin and Rood (1996), the deep convective scheme of Zhang and McFarlane (1995), the shallow convection scheme of Hack (1994), the wet deposition scheme of Liu et al. (2001), and the dry deposition scheme of Wesely (1989) and Wang et al. (1998). The instantaneous vertical mixing in the planetary boundary layer (PBL) is accounted for by the TURBDAY mixing scheme (Bey et al., 2001). The average PBL height in wintertime in the US is about $480 \mathrm{~m}$ and occupies the lowest 3-6 vertical model layers.

We simulate aerosols for the years 1986-2006 driven by the GEOS-4 reanalysis data. The years of 1986-2006 are chosen for chemistry-aerosol simulation because these are the years that the GEOS- 4 data sets are available. Global anthropogenic emissions are from the Global Emissions Inventory Activity (GEIA) (Park et al., 2004, 2006; Zhu et al., 2012; Yang et al., 2015). Anthropogenic emissions over the US are overwritten by the US EPA National Emission Inventory for 1999 (NEI99), which have monthly variations in emissions of precursors including $\mathrm{SO}_{2}, \mathrm{NO}_{x}$, and $\mathrm{NH}_{3}$. Monthly biomass burning emissions are taken from the Global Fire Emissions Database version 2 (GFED-2) (Giglio et al., 2006; van der Werf et al., 2006). During the simulation of aerosols for the years 1986-2006, the global anthropogenic and biomass burning emissions of aerosols and aerosol precursors are fixed at year 2005 levels, so that the variations in aerosol concentrations are caused by variations in meteorological parameters alone. non-methane volatile organic compounds (NMVOCs) and $\mathrm{NO}_{x}$ from light- ing and soil, are allowed to vary over 1986-2006 following the variations in the GEOS-4 meteorological parameters. Biogenic NMVOC emissions are calculated using the module of Model of Emissions of Gases and Aerosols from Nature (MEGAN) (Guenther et al., 2006). Lightning $\mathrm{NO}_{x}$ emissions are described by Sauvage et al. (2007) and Murray et al. (2012). Soil $\mathrm{NO}_{x}$ emissions are calculated using the algorithm proposed by Yienger and Levy (1995).

The GEOS-Chem simulation of aerosols in the US have been evaluated extensively by previous studies (Park et al., 2003, 2004, 2005; Heald et al., 2006, 2008; van Donkelaar et al., 2006, 2008; Liao et al., 2007; Fu et al., 2009; Drury et al., 2010; Leibensperger et al., 2011; Zhang et al., 2012). These studies have shown that the GEOS-Chem model can capture the magnitudes and distributions of aerosols in the US. The $\mathrm{OH}$ concentrations in GEOS-Chem were examined by previous studies (Holmes et al., 2013; Wu et al., 2007) by calculating the methane lifetime, which agreed closely with the lifetime of $11.2 \pm 1.3$ years constrained by methyl chloroform observations by Prather et al. (2012). Previous studies also showed that aerosol concentrations were not so sensitive to $\mathrm{OH}$ concentrations in the GEOS-Chem simulations (Heald et al., 2012).

\subsection{PNA index}

The PNA index (PNAI) is commonly used to quantify the changes in PNA phase (Wallace and Gutzler, 1981; Leathers et al., 1991). This study follows the definition of PNAI by Leathers et al. (1991). In order to examine the monthly variations in PNA, the mean seasonal cycle of geopotential height at $700 \mathrm{hPa}$ is removed for the months of November, December, January, February, and March (NDJFM) in the studied years. Such a deseasonality approach has been used in the analyses of the growth and decay of the PNA phase in NDJFM (Feldstein, 2002), the development of NAO (Feldstein, 2003), the influence of NAO on precipitation in Europe (Qian et al., 2000), and the variations in Madden-Julian oscillation (Wheeler and Hendon, 2004). If we are concerned with the PNAI during $n$ years, the monthly PNAI in month $j$ ( $j$ is one of the 5 months of NDJFM) of year $i$ is calculated by

$$
\begin{aligned}
\text { PNAI }= & \frac{1}{3}\left[-Z_{i, j}^{* \prime}\left(47.9^{\circ} \mathrm{N}, 170^{\circ} \mathrm{W}\right)+Z_{i, j}^{* \prime}\right. \\
& \left.\left(47.9^{\circ} \mathrm{N}, 110^{\circ} \mathrm{W}\right)-Z_{i, j}^{* \prime}\left(29.7^{\circ} \mathrm{N}, 86.3^{\circ} \mathrm{W}\right)\right]
\end{aligned}
$$

where $Z_{i, j}^{* \prime}=\frac{Z_{i, j}^{\prime}}{\sqrt{\frac{1}{n \times 5} \sum_{i=1}^{n} \sum_{j=1}^{5} Z_{i, j}^{\prime}}}$ and $Z_{i, j}^{\prime}=Z_{i, j}-\frac{1}{n} \sum_{i=1}^{n} Z_{i, j}$. Therefore, $Z_{i, j}^{\prime}$ denotes the removal of seasonal cycle, and $Z_{i, j}^{* \prime}$ denotes the standardized anomaly of geopotential height at $700 \mathrm{hPa}$ in month $j$ of year $i$ with seasonal cycle removed.

The PNAI is calculated by using both the National Center of Environmental Prediction - Department of Energy Reanalysis 2 data (NCEP-2; horizontal resolu- 


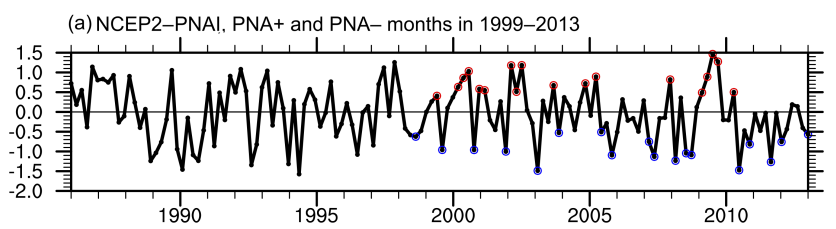

(b) NCEP2-PNAI, PNA+ and PNA- months in 2000-2013

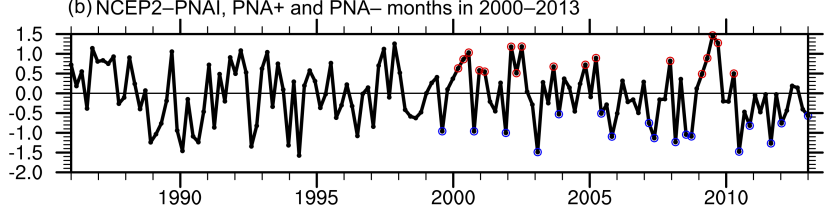

(c) GEOS4-PNAI, PNA+ and PNA- months in 1986-2006

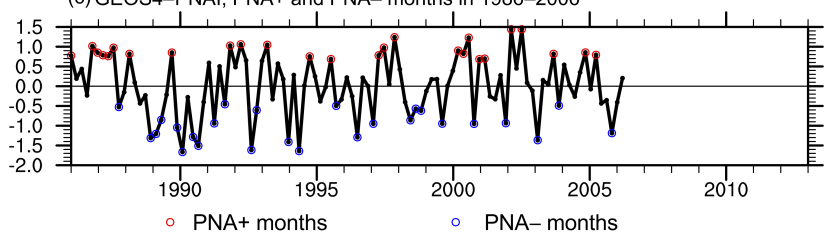

Figure 2. (a) PNAI for the years 1986-2013 calculated using the NCEP-2 data (NCEP2-PNAI), with the PNA+ and PNA - months during 1999-2013 indicated. (b) PNAI for the years 1986-2013 calculated using the NCEP-2 data, with the PNA+ and PNAmonths during 2000-2013 indicated. (c) PNAI for the years 19862006 calculated using the GEOS-4 data (GEOS4-PNAI), with the PNA+ and PNA - months over 1986-2006 indicated. Red circles are PNA+ months and blue circles PNA- months. The PNA+ (PNA-) months are defined as the $25 \%$ of winter months examined, which have the highest positive (negative) PNA index values.

tion $2.5^{\circ} \times 2.5^{\circ}$ globally; http://www.esrl.noaa.gov/psd/data/ gridded/data.ncep.reanalysis2.html) for the years 1986-2013 (referred to as NCEP2-PNAI) and the GEOS-4 assimilated meteorological data (referred to as GEOS4-PNAI) for 1986-2006 (Fig. 2). Both series of PNA index show strong monthly variations (Fig. 2), and the GEOS4-PNAI agrees with NCEP2-PNAI over 1986-2006 with a high correlation coefficient of 0.99, indicating that the NCEP-2 and GEOS-4 data sets are consistent in representing the monthly variations of PNAI.

There are $n \times 5$ PNAI values for $n$ years, since we calculate PNAI for the months of NDJFM of each year. These $n \times 5$ PNAI values are classified into three categories for our composite analyses of aerosol concentrations and meteorological parameters: the positive PNA months (PNA+) that are $25 \%$ of the $n \times 5$ PNAI months with the highest positive PNAI values, the negative PNA months (PNA-) that are $25 \%$ of the $n \times 5$ PNAI months with the highest negative PNAI values, and the rest months that are referred to as the transitional months (Fig. 2).
Table 1. The absolute $\left(\mu \mathrm{g} \mathrm{m}^{-3}\right)$ and relative $(\%)$ differences in observed aerosol concentrations between the PNA+ and PNAmonths (PNA + minus PNA-). The observed concentrations are averaged over all the sites in the whole of US, in the western US, or in the eastern US. See Fig. 1 for locations of the sites. The measurements are from the EPA-AQS data.

\begin{tabular}{llll}
\hline & Whole US & Western US & Eastern US \\
\hline $\mathrm{PM}_{2.5}$ & $1.0(8.7 \%)^{\mathrm{b}}$ & $1.3(14.3 \%)^{\mathrm{b}}$ & $0.8(7.2 \%)^{\mathrm{b}}$ \\
$\mathrm{SO}_{4}^{2-}$ & $0.01(0.5 \%)$ & $0.03(3.2 \%)$ & $0.1(3.7 \%)$ \\
$\mathrm{NO}_{3}^{-}$ & $0.3(29.1 \%)^{\mathrm{b}}$ & $0.2(23.8 \%)^{\mathrm{b}}$ & $0.4(36.5 \%)^{\mathrm{b}}$ \\
$\mathrm{NH}_{4}^{+}$ & $0.1(11.9 \%)^{\mathrm{a}}$ & $0.2(31.6 \%)^{\mathrm{b}}$ & $0.1(10.5 \%)$ \\
$\mathrm{OC}$ & $0.6(13.5 \%)^{\mathrm{b}}$ & $0.9(17.7 \%)^{\mathrm{b}}$ & $0.3(8.0 \%)^{\mathrm{b}}$ \\
$\mathrm{BC}$ & $0.2(27.8 \%)^{\mathrm{b}}$ & $0.2(25.0 \%)^{\mathrm{b}}$ & $0.1(25.2 \%)^{\mathrm{b}}$ \\
\hline
\end{tabular}

The ${ }^{\mathrm{a}}$ and ${ }^{\mathrm{b}}$ indicate the differences that have passed the two-tail student $t$ test with 90 and $95 \%$ significance levels, respectively.

\section{Impacts of PNA on observed aerosol concentrations}

The measurements of $\mathrm{PM}_{2.5}$ are available over 1999-2013, in which there were $18 \mathrm{PNA}+$ months and $18 \mathrm{PNA}-$ months as shown in Fig. 2a. Figure 3 shows the differences in observed surface-layer $\mathrm{PM}_{2.5}$ concentrations between the PNA+ and PNA - months (concentrations averaged over the 18 PNA+ months minus those averaged over the 18 PNA- months). The uncertainty associated with the differences in aerosol concentrations between PNA+ and PNA- months is represented by the two-tail Student $t$ test with significance level of $90 \%$. Among 1044 sites with $\mathrm{PM}_{2.5}$ concentrations (Fig. 1), $42 \%$ of which had statistically significant differences in $\mathrm{PM}_{2.5}$ between PNA+ and PNA- months. Relative to the PNA- months, $\mathrm{PM}_{2.5}$ concentrations in PNA+ months were higher in California, the contiguous Salt Lake (northern Utah), and over and near the eastern Midwest. The maximum enhancement of $\mathrm{PM}_{2.5}$ reached 7-9 $\mu \mathrm{g} \mathrm{m}^{-3}$ (or $40-80 \%$ ) in California, 7-9 $\mu \mathrm{g} \mathrm{m}^{-3}(80-100 \%$ ) around Salt Lake, $3-5 \mu \mathrm{g} \mathrm{m}^{-3}(40-80 \%)$ over and near the eastern Midwest. At sites in North Dakota, Wisconsin, Michigan, Minnesota, Montana, Texas, and Maine, the $\mathrm{PM}_{2.5}$ concentrations were lower by up to $2 \mu \mathrm{g} \mathrm{m}^{-3}(-10$ to $-20 \%)$ in $\mathrm{PNA}+$ months than in PNA- months. As the concentrations are averaged over all sites (including the sites that pass and do not pass the $t$ test with $90 \%$ confidence level) in the US, the western US (west of $100^{\circ} \mathrm{W}$, Fig. 1), and the eastern US (east of $100^{\circ} \mathrm{W}$, Fig. 1), $\mathrm{PM}_{2.5}$ concentrations were higher by $1.0 \mu \mathrm{g} \mathrm{m}^{-3}(8.7 \%), 1.3 \mu \mathrm{g} \mathrm{m}^{-3}(14.3 \%)$, and $0.8 \mu \mathrm{g} \mathrm{m}^{-3}$ $(7.2 \%)$, respectively, in the PNA+ months than in PNAmonths (Table 1).

The measurements of speciated aerosols are available during 2000-2013, in which there were 17 PNA+ and 17 PNAmonths (Fig. 2b). Figure 3 also shows the differences in observed surface-layer concentrations of individual aerosol species between the PNA+ and PNA- months. The dif- 


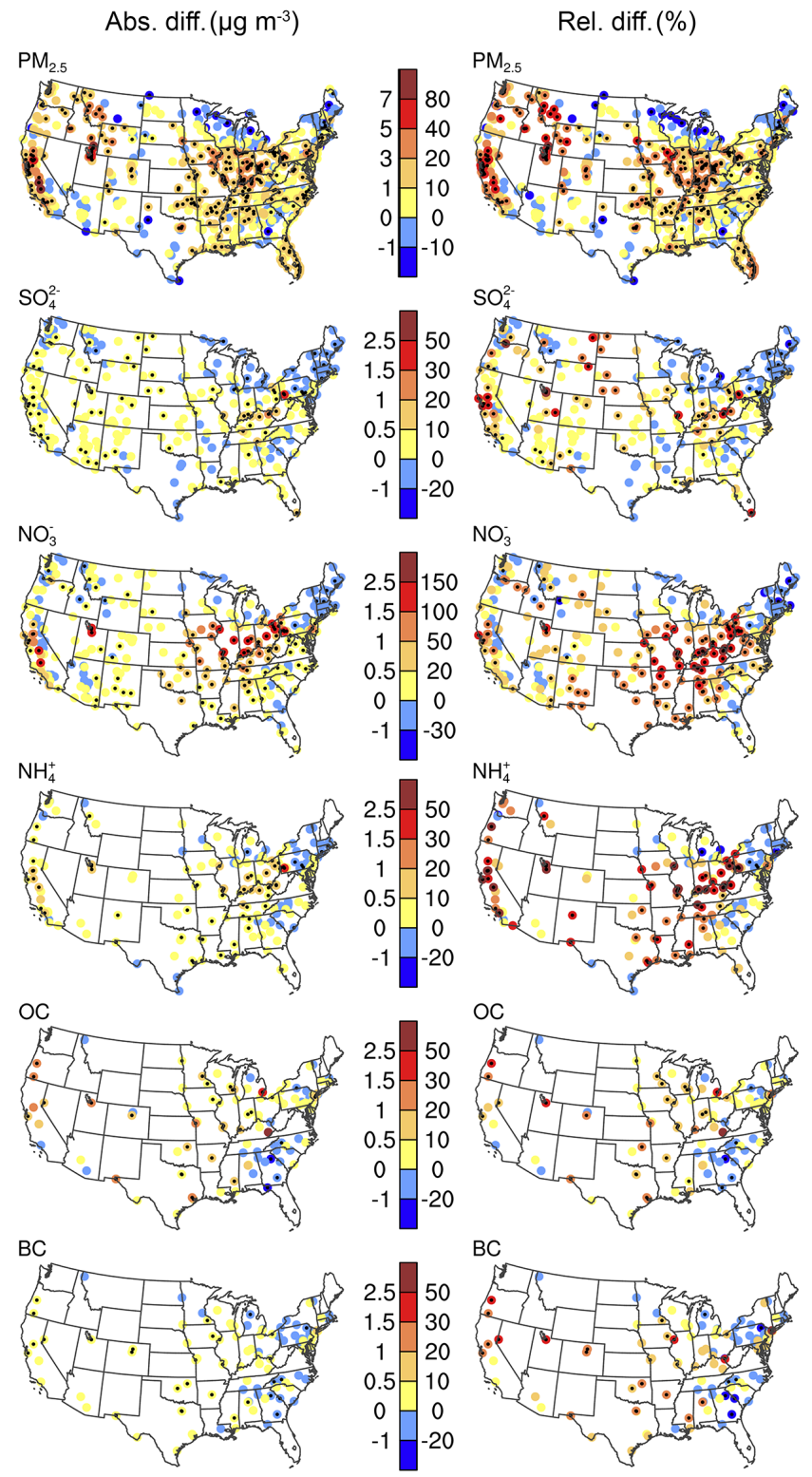

Figure 3. The absolute ( $\mu \mathrm{g} \mathrm{m}^{-3}$, left column) and relative differences (\%, right column) in observed monthly mean aerosol concentrations between PNA + and PNA - months (PNA+ minus PNA-). See Fig. 2c for the definitions of PNA+ and PNA- months. The measurements of $\mathrm{PM}_{2.5}$ were carried out over 1999-2013, in which there were 18 PNA+ months and 18 PNA- months as shown in Fig. 2a. The measurements of speciated aerosols were taken during 2000-2013, in which there were 17 PNA+ and 17 PNA- months (Fig. 2b). The seasonal cycle and trend in observed aerosol concentrations were removed as described in Sect. 2.1. The sites with black dots were the differences that passed the two-tail $t$ test with $90 \%$ confidence level.

ferences in concentrations of $\mathrm{SO}_{4}^{2-}, \mathrm{NO}_{3}^{-}$, and $\mathrm{NH}_{4}^{+}$show statistically significant positive values at most sites. Among the 355,343 , and 194 sites with measurements of $\mathrm{SO}_{4}^{2-}$,
$\mathrm{NO}_{3}^{-}$, and $\mathrm{NH}_{4}^{+}, 30,44$, and $39 \%$ of which pass the twotail $t$ test with $90 \%$ confidence level, respectively. While the absolute differences in concentrations of $\mathrm{SO}_{4}^{2-}, \mathrm{NO}_{3}^{-}$, and $\mathrm{NH}_{4}^{+}$between PNA+ and PNA- were in the range of 0 $1 \mu \mathrm{g} \mathrm{m}^{-3}$ at most sites, the maximum differences reached $1.5-2.5 \mu \mathrm{g} \mathrm{m}^{-3}$ (30-50\%) for $\mathrm{SO}_{4}^{2-}$ in Pennsylvania, 1.5$2.5 \mathrm{\mu g} \mathrm{m}^{-3}(150-200 \%)$ for $\mathrm{NO}_{3}^{-}$in Illinois, Indiana, and Ohio, and $1.5-2.5 \mu \mathrm{g} \mathrm{m}^{-3}$ (50-70\%) for $\mathrm{NH}_{4}^{+}$in Pennsylvania. Averaged over the sites with measurements, the absolute differences in concentrations of $\mathrm{SO}_{4}^{2-}$ and $\mathrm{NO}_{3}^{-}$between $\mathrm{PNA}+$ and PNA - months were larger in the eastern US than in the western US. As shown in Table 1, the differences in the averaged concentrations of $\mathrm{SO}_{4}^{2-}, \mathrm{NO}_{3}^{-}$, and $\mathrm{NH}_{4}^{+}$were, respectively, $0.1 \mu \mathrm{g} \mathrm{m}^{-3}$ (3.7\%), $0.4 \mu \mathrm{g} \mathrm{m}^{-3}$ (36.5\%), and $0.1 \mu \mathrm{g} \mathrm{m}^{-3}(10.5 \%)$ in the eastern US, $0.03 \mu \mathrm{g} \mathrm{m}^{-3}(3.2 \%)$, $0.2 \mu \mathrm{g} \mathrm{m}^{-3}(23.8 \%)$, and $0.2 \mu \mathrm{g} \mathrm{m}^{-3}(31.6 \%)$ in the western $\mathrm{US}$, as well as $0.01 \mu \mathrm{g} \mathrm{m}^{-3}(0.5 \%), 0.3 \mu \mathrm{g} \mathrm{m}^{-3}(29.1 \%)$, and $0.1 \mu \mathrm{g} \mathrm{m}^{-3}(11.9 \%)$ in the whole of US.

With regard to carbonaceous aerosols, among the 105 and 104 sites with measurements of $\mathrm{OC}$ and $\mathrm{BC}, 39$ and $31 \%$ of which pass the two-tail $t$ test with $90 \%$ confidence, respectively, the differences in concentrations of these two species between PNA+ and PNA - months show similar geographical pattern, with positive values at most sites but negative values in Michigan, New York, and the south Atlantic states. The maximum differences between the PNA+ and PNAmonths reached $2.5-3 \mu \mathrm{g} \mathrm{m}^{-3}(50-70 \%)$ in Kentucky for OC. Averaged over sites with measurements available, the absolute differences in $\mathrm{OC}$ and $\mathrm{BC}$ concentrations between the PNA+ and PNA- months were larger in the western US than in the eastern US (Table 1). Among all aerosol species listed in Table 1, OC exhibited the largest absolute differences between the PNA phases in the western US, because OC accounts for 25-65\% of $\mathrm{PM}_{2.5}$ in the western US (Malm et al., 2004) and the OC observed by EPA-AQS network, which are located in urban and suburban settings, were higher than the observations by other long-term networks in US (Malm et al., 2011; Rattigan et al., 2011, Hand et al., 2012b, 2014).

Observations from EPA-AQS data sets indicate the large impacts of PNA phase on aerosol concentrations in the US. It should be noted that, in our analyses above, the locations of measurements and the numbers of samples were different for different aerosol species. The regional averages were also influenced by the uneven distributions of observational sites in different regions. Therefore, model results from the GEOS-Chem simulation will be used to further analyze the impacts of PNA on aerosols in the US, as presented in the subsequent sections.

We have also calculated the correlation coefficient between PNAI and EPA-AQS surface aerosol concentrations at each site for each aerosol species $\left(\mathrm{PM}_{2.5}, \mathrm{SO}_{4}^{2-}, \mathrm{NO}_{3}^{-}\right.$, $\mathrm{NH}_{4}^{+}, \mathrm{OC}$, or BC) (see Fig. S2). About 40, 30, 47, 33, 33 , and $34 \%$ of sites pass the two-tail $t$ test with $90 \%$ 
confidence for $\mathrm{PM}_{2.5}, \mathrm{SO}_{4}^{2-}, \mathrm{NO}_{3}^{-}, \mathrm{NH}_{4}^{+}$, OC, and $\mathrm{BC}$, respectively. At most sites, positive (negative) correlation coefficients in Fig. S2 corresponded to the increases (decreases) in aerosol concentration in PNA+ months relative to PNA- months shown in Fig. 3. Positive correlation coefficients were large over California, the contiguous Salt Lake, and over and near the eastern Midwest. The fraction of temporal variability explained by PNA (FTVEP) can be quantified approximately by the square of correlation coefficient (http://mathbits.com/MathBits/TISection/ Statistics2/correlation.htm) (see Fig. S3). For all aerosol species, FTVEP were about 5-15\% at most sites. For $\mathrm{PM}_{2.5}$, $\mathrm{SO}_{4}^{2-}, \mathrm{NO}_{3}^{-}$, and $\mathrm{NH}_{4}^{+}$aerosols, FTVEP values were high over and near the eastern Midwest, where the PNA teleconnection explained up to $50,40,50$, and $40 \%$ of temporal variances of surface concentrations of these aerosol species, respectively.

\section{Impacts of PNA on simulated aerosol concentrations}

\subsection{Simulated aerosol concentrations and model evaluation}

Figure $4 \mathrm{a}$ shows the simulated surface-layer concentrations of $\mathrm{PM}_{2.5}$ (the sum of $\mathrm{SO}_{4}^{2-}, \mathrm{NO}_{3}^{-}, \mathrm{NH}_{4}^{+}, \mathrm{BC}$, and $\mathrm{OC}$ ) and each aerosol species averaged over NDJFM of 1999-2006. These years are selected because they are the common years of model results and EPA-AQS observation data sets. The simulated $\mathrm{PM}_{2.5}$ concentrations were higher in the eastern US than in the western US. The maximum surface $\mathrm{PM}_{2.5}$ concentrations reached $14-16 \mu \mathrm{g} \mathrm{m}^{-3}$ in Ohio and Pennsylvania. $\mathrm{PM}_{2.5}$ concentrations in the western US were generally less than $4 \mu \mathrm{g} \mathrm{m}^{-3}$, except for California where $\mathrm{PM}_{2.5}$ concentrations were $2-6 \mu \mathrm{g} \mathrm{m}^{-3}$. The distribution of $\mathrm{SO}_{4}^{2-}$ was similar to that of $\mathrm{PM}_{2.5}$, with higher concentrations in the eastern US $\left(1-8 \mu \mathrm{g} \mathrm{m}^{-3}\right)$ than in the western US (0$3 \mu \mathrm{g} \mathrm{m}^{-3}$ ) due to the coal-fired power plants in the Midwest (Park et al., 2006). The concentrations of $\mathrm{NO}_{3}^{-}$and $\mathrm{NH}_{4}^{+}$ were the highest over and near the eastern Midwest, with values of $3-4$ and $2-3 \mu \mathrm{g} \mathrm{m}^{-3}$, respectively. The maximum OC concentrations were simulated to be $2-3 \mu \mathrm{g} \mathrm{m}^{-3}$ in two regions, from Ohio to Massachusetts and from Alabama to South Carolina. The simulated BC concentrations in the US were $0-1 \mu \mathrm{g} \mathrm{m}^{-3}$, except for the contiguous New York where $\mathrm{BC}$ concentrations reached $1-2 \mu \mathrm{g} \mathrm{m}^{-3}$. The magnitudes and geographic distributions of $\mathrm{SO}_{4}^{2-}, \mathrm{NO}_{3}^{-}, \mathrm{NH}_{4}^{+}$concentrations simulated in our work are similar to those simulated by Park et al. (2006) and Pye et al. (2009), and our simulated $\mathrm{OC}$ and $\mathrm{BC}$ were similar to those reported by Park et al. (2003).

Figure $4 \mathrm{~b}$ presents the scatter plots of the simulated concentrations versus the EPA-AQS observations. The simulated $\mathrm{PM}_{2.5}$ concentrations had normalized mean bias $(\mathrm{NMB}=$ $\sum_{m=1}^{M}\left(S_{m}-O_{m}\right) / \sum_{m=1}^{M}\left(O_{m}\right) \times 100 \%$, where $S_{m}$ and $O_{m}$ (a) Mean conc. $\left(\mu \mathrm{g} \mathrm{m}^{-3}\right)$

(b) Scatter plot

(c) Deviation from the mean
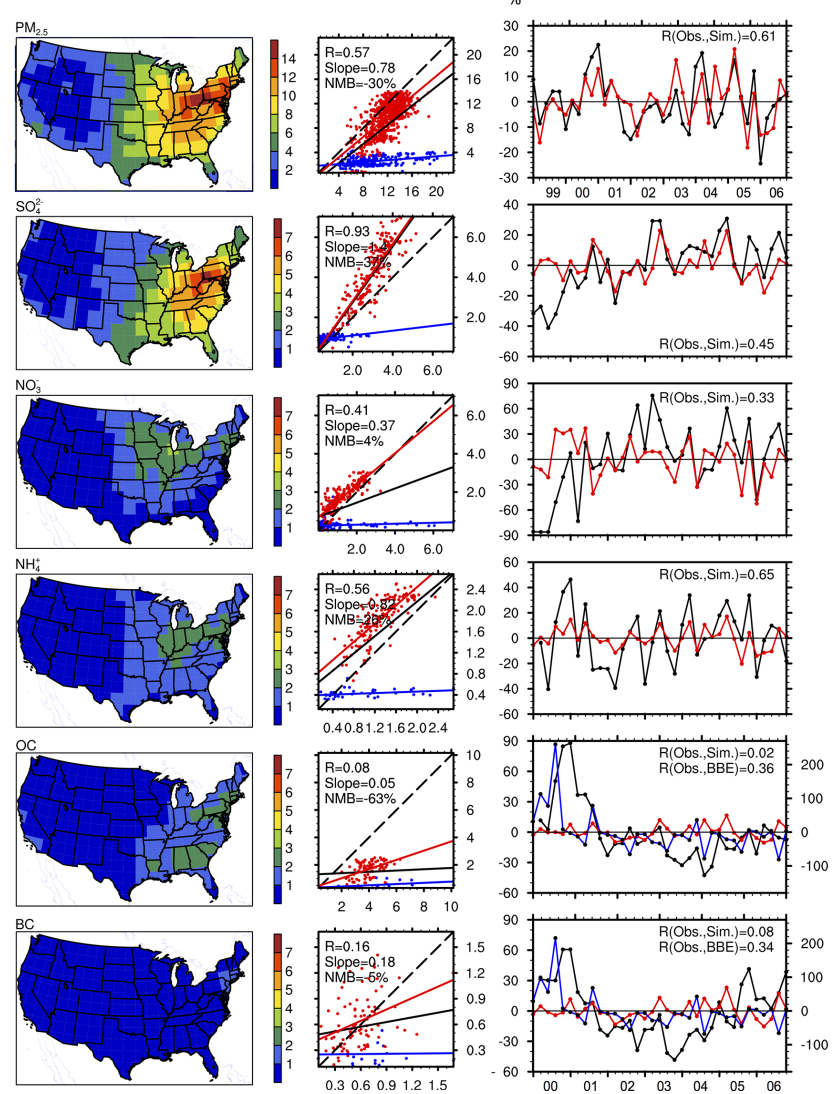

Figure 4. (a) Simulated surface-layer concentrations $\left(\mu \mathrm{g} \mathrm{m}^{-3}\right)$ of $\mathrm{PM}_{2.5}$ (the sum of $\mathrm{SO}_{4}^{2-}, \mathrm{NO}_{3}^{-}, \mathrm{NH}_{4}^{+}, \mathrm{BC}$, and $\mathrm{OC}$ ) and each aerosol species averaged over NDJFM of 1999-2006. (b) Scatter plots of the simulated concentrations ( $\mu \mathrm{g} \mathrm{m}^{-3}$, vertical axis) versus the EPA-AQS observations ( $\mu \mathrm{g} \mathrm{m}^{-3}$, horizontal axis). Also shown are the $y=x$ line (black dash line), linear fit for whole US (black line), linear fit for western US (blue line), and linear fit for eastern US (red line). The blue and red dots represent sites in the western and eastern US, respectively. (c) Comparisons of the deviation from the mean (DM) of observed concentration (black line) with that of simulated concentration (red line) in each winter month for each aerosol species, left axis. Also shown in the panel for OC (BC) the monthly variation in DM of biomass burning emission of $\mathrm{OC}(\mathrm{BC})$, blue line, right axis.

are the simulated and observed aerosol concentrations in month $m$, respectively. $M$ is the total number of winter months examined) of $-30 \%$ over the US, and the correlation coefficient between simulated and observed $\mathrm{PM}_{2.5}$ concentrations was 0.57 . The simulated wintertime $\mathrm{SO}_{4}^{2-}, \mathrm{NO}_{3}^{-}$, and $\mathrm{NH}_{4}^{+}$had NMBs of 37, 4, and $26 \%$, respectively. Similar bias in simulated $\mathrm{SO}_{4}^{2-}$ in December-January-February (DJF) was reported Park et al. (2006), as the GEOS-Chem model results were compared with observations from the Clean Air Status and Trends Network (CASTNET). The high bias in our simulated $\mathrm{NH}_{4}^{+}$was associated with the overestimation 
of $\mathrm{SO}_{4}^{2-}$. Our model underestimates $\mathrm{PM}_{2.5}, \mathrm{SO}_{4}^{2-}, \mathrm{NO}_{3}^{-}$, $\mathrm{NH}_{4}^{+}, \mathrm{OC}$, and $\mathrm{BC}$ in the western US (Fig. 4b), which can be explained in part by the relatively high aerosol concentrations observed for this region from the EPA-AQS. Hand et al. (2014) compared the observed concentrations of aerosols from the EPA-AQS with those from the Interagency Monitoring of Protected Visual Environments (IMPROVE) for 20082011, and showed that the ratios of wintertime aerosol concentrations of ammonium sulfate, ammonium nitrate, OC, and $\mathrm{BC}$ from the $\mathrm{EPA}-\mathrm{AQS}$ to those from the IMPROVE were, respectively, 2.3, 7.7, 8.3, and 13.1, as the concentrations were averaged over the western US. Liu et al. (2004) also attributed the high EPA-AQS concentrations in the western US to the relative sparse urban sites that were heavily influenced by strong local sources such as automobiles and wood fires. The low model biases in the western US may also be caused by the biases in emissions in the model.

Since this study is dedicated to examine the influence of PNA phase on the month-to-month variations of aerosol concentrations during wintertime, Fig. 4c compares, for each aerosol species, the deviation from the mean (DM) of observed concentration with that of simulated concentration for each winter month. The DM is defined as $\mathrm{DM}_{m}=$ $\left(C_{m}-\frac{1}{M} \sum_{m=1}^{M} C_{m}\right) / \frac{1}{M} \sum_{m=1}^{M} C_{m}$, where $C_{m}$ is the simulated average aerosol concentration over the US in month $m$, and $M$ is the number of winter months examined (we consider the months of NDJFM over 1999-2006 for $\mathrm{PM}_{2.5}$, and the months of NDJFM over 2000-2006 for $\mathrm{SO}_{4}^{2-}, \mathrm{NO}_{3}^{-}$, $\mathrm{NH}_{4}^{+}, \mathrm{BC}$, and $\mathrm{OC}$ ). The model captures fairly well the peaks and troughs of $\mathrm{DMs}$ for $\mathrm{PM}_{2.5}, \mathrm{SO}_{4}^{2-}, \mathrm{NO}_{3}^{-}$, and $\mathrm{NH}_{4}^{+}$, with correlation coefficients of $0.61,0.45,0.33$, and 0.65 , respectively. The model does not capture well the monthly variations of DMs of concentrations of OC and BC, because both anthropogenic and biomass burning emissions are fixed at year 2005 levels during our simulation over 1986-2006 to isolate the impacts of variations in meteorological parameters (PNA phases) on aerosols (see Sect. 2.2). Since the biomass burning emissions, which contribute largely to carbonaceous aerosols, have large interannual variations (Duncan et al., 2003; Generoso et al., 2003; van der Werf et al., 2006), we also show in Fig. 4c the time series of DMs of biomass burning emissions of $\mathrm{OC}$ and $\mathrm{BC}$ by using biomass burning emissions in NDJFM over 2000-2006 from GFED v2. The correlation coefficients between biomass burning emissions and observed concentrations of $\mathrm{OC}$ and $\mathrm{BC}$ were 0.36 and 0.34 , respectively, indicating that the observed variations in $\mathrm{OC}$ and $\mathrm{BC}$ were influenced by monthly and interannual variations in biomass burning. We have also calculated the temporal correlation coefficient between EPAAQS observations and GEOS-Chem model results at each site for each aerosol species (Fig. S4). The temporal correlations were statistically significant for $\mathrm{PM}_{2.5}, \mathrm{SO}_{4}^{2-}, \mathrm{NO}_{3}^{-}$, $\mathrm{NH}_{4}^{+}$at most sites in the US, especially over and near the eastern Midwest where largest increases in aerosol concen-

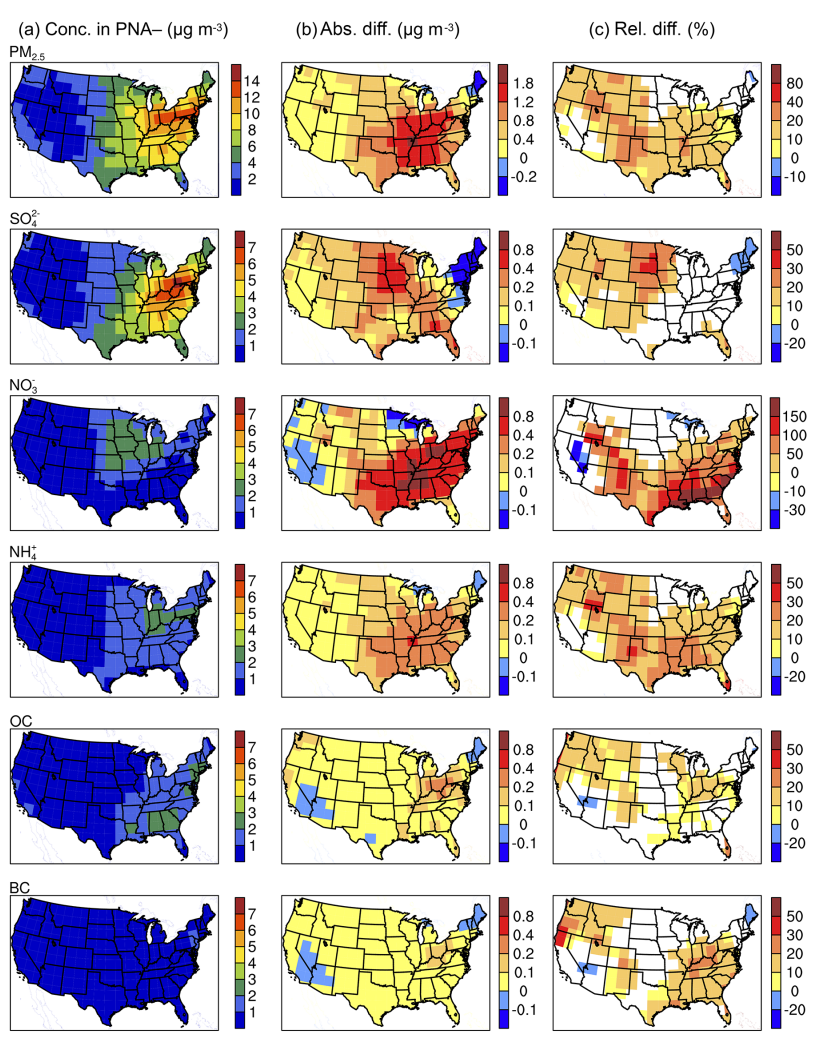

Figure 5. (a) Simulated concentrations $\left(\mu \mathrm{g} \mathrm{m}^{-3}\right)$ of $\mathrm{PM}_{2.5}$ and each aerosols species averaged over the PNA- months of 1986-2006. (b) The absolute differences $\left(\mu \mathrm{g} \mathrm{m}^{-3}\right)$ in simulated aerosol concentrations between PNA+ and PNA- months (PNA+ minus PNA-). (c) The relative differences $(\%)$ in simulated aerosol concentrations between PNA+ and PNA- months. The white spaces in (c) indicate the areas that did not pass the two-tail student $t$ test with $90 \%$ significance level. The seasonal cycles of simulated aerosol concentrations were removed. See Fig. 2c for the definitions of PNA+ and PNA- months.

trations were identified in the PNA+ months relative to the PNA- months.

\subsection{Impact of PNA on simulated surface-layer aerosol concentrations}

We have performed the GEOS-Chem simulation for the years 1986-2006, in which there were 35 PNA+ and 35 PNAmonths (Fig. 2). Figure 5a shows the concentrations of $\mathrm{PM}_{2.5}$ and each aerosols species $\left(\mathrm{SO}_{4}^{2-}, \mathrm{NO}_{3}^{-}, \mathrm{NH}_{4}^{+}, \mathrm{BC}\right.$, and $\left.\mathrm{OC}\right)$ averaged over the PNA- months of 1986-2006. The magnitudes and geographic distributions of aerosol concentrations in PNA - months were similar to those averaged over NDJFM of years 1999-2006 in Fig. 4.

The simulated absolute and relative differences in aerosol concentrations between PNA+ and PNA - months are shown in Fig. $5 b$ and c. The $\mathrm{PM}_{2.5}$ concentrations over the US are simulated to increase in PNA+ relative to PNA- months. 
Table 2. The absolute $\left(\mu \mathrm{g} \mathrm{m}^{-3}\right)$ and relative $(\%)$ differences in simulated aerosol concentrations between the PNA+ and PNAmonths $(\mathrm{PNA}+$ minus PNA-). The simulated concentrations are averaged over the whole of US, the western US (west of $100^{\circ} \mathrm{W}$ ), or the eastern US (east of $100^{\circ} \mathrm{W}$ ). The concentrations are from the GEOS-Chem simulation for 1986-2006.

\begin{tabular}{llll}
\hline & Whole US & Western US & Eastern US \\
\hline $\mathrm{PM}_{2.5}$ & $0.6(12.2 \%)^{*}$ & $0.3(14.0 \%)^{*}$ & $0.9(10.8 \%)^{*}$ \\
$\mathrm{SO}_{4}^{2-}$ & $0.2(7.1 \%)$ & $0.1(13.5 \%)^{*}$ & $0.2(4.0 \%)$ \\
$\mathrm{NO}_{3}^{-}$ & $0.2(30.3 \%)^{*}$ & $0.1(28.5)^{*}$ & $0.4(33.5 \%)^{*}$ \\
$\mathrm{NH}_{4}^{+}$ & $0.2(14.4 \%)^{*}$ & $0.1(15.4 \%)^{*}$ & $0.2(13.2 \%)^{*}$ \\
$\mathrm{OC}$ & $0.05(6.5 \%)^{*}$ & $0.03(8.6 \%)^{*}$ & $0.08(5.9 \%)^{*}$ \\
$\mathrm{BC}$ & $0.03(10.2 \%)^{*}$ & $0.01(8.6 \%)^{*}$ & $0.05(11.0 \%)^{*}$ \\
\hline
\end{tabular}

The * indicate the differences that have passed the two-tail student $t$ test with $95 \%$ significance levels.

The maximum enhancement in $\mathrm{PM}_{2.5}$ concentrations in PNA + months was $1.8-2.4 \mu \mathrm{g} \mathrm{m}^{-3}(20-40 \%)$, located in the juncture of Tennessee and Arkansas. Note that the pattern of simulated differences in $\mathrm{PM}_{2.5}$ between PNA+ and PNA-months was similar to that of observations (Fig. 3), except that the simulated differences were not large in California, mainly due to the underestimation of OC in California as compared to EPA-AQS data (Fig. 4b). The simulated $\mathrm{PM}_{2.5}$ concentrations were higher by $0.6 \mu \mathrm{g} \mathrm{m}^{-3}(12.2 \%)$, $0.3 \mu \mathrm{g} \mathrm{m}^{-3}(14.0 \%)$, and $0.9 \mu \mathrm{g} \mathrm{m}^{-3}(10.8 \%)$ over the whole of western and eastern US, respectively, in the PNA+ months than in PNA - months (Table 2). The simulated relative difference in $\mathrm{PM}_{2.5}$ was close to that from observations (Table 1) in the western US, but the simulated relative differences in $\mathrm{PM}_{2.5}$ were larger than those from observations in the eastern and whole of US.

Figure 5 also shows the differences in simulated surfacelayer concentrations of $\mathrm{SO}_{4}^{2-}, \mathrm{NO}_{3}^{-}$, and $\mathrm{NH}_{4}^{+}$between the $\mathrm{PNA}+$ and the PNA- months. The differences in concentrations of $\mathrm{SO}_{4}^{2-}$ were larger in the western than in the eastern US, with maximum enhancements of $0.4-0.8 \mu \mathrm{g} \mathrm{m}^{-3}$ (30$50 \%$ ) over the western north-central states (South Dakota, Nebraska, Minnesota, Iowa, and Missouri). The differences in concentrations of $\mathrm{NO}_{3}^{-}$and $\mathrm{NH}_{4}^{+}$between PNA+ and PNA - months had similar geographical patterns, with increases in concentrations in a large fraction of the eastern US and over a belt region along the Rocky Mountains in the western US. The increases in concentrations of $\mathrm{NO}_{3}^{-}$ and $\mathrm{NH}_{4}^{+}$over the eastern US in PNA + months relative to PNA - months agreed very well with those seen in observations in most regions of the US (Fig. 3). The model underestimates the differences in $\mathrm{NO}_{3}^{-}$in California and the southeastern US, because the model does not capture well the temporal variations of $\mathrm{NO}_{3}^{-}$in these two regions (Fig. S4). The differences in concentrations of $\mathrm{SO}_{4}^{2-}, \mathrm{NO}_{3}^{-}$, and $\mathrm{NH}_{4}^{+}$in the eastern US between the PNA+ and PNA- months were $0.2 \mu \mathrm{g} \mathrm{m}^{-3}$ (4.0\%), $0.4 \mu \mathrm{g} \mathrm{m}^{-3}(33.5 \%)$, and $0.2 \mu \mathrm{g} \mathrm{m}^{-3}(13.2 \%)$, respectively (Table 2 ).

The differences in concentrations of $\mathrm{OC}$ and $\mathrm{BC}$ between $\mathrm{PNA}+$ and PNA - months had similar geographical patterns, with large increases in concentrations over and near the eastern Midwest and the region from northwestern US to Texas. The maximum differences reached $0.2-0.4 \mu \mathrm{g} \mathrm{m}^{-3}$ $(10-20 \%)$ and $0.1-0.2 \mu \mathrm{g} \mathrm{m}^{-3}(20-30 \%)$ in Illinois, Indiana, and Ohio for $\mathrm{OC}$ and $\mathrm{BC}$, respectively. The magnitudes of the differences in $\mathrm{OC}$ and $\mathrm{BC}$ were statistically significant but were smaller than the observations (Tables 1 and 2). The absolute differences in $\mathrm{OC}$ were less than $0.1 \mathrm{~g} \mathrm{~m} \mathrm{~m}^{-3}$ in the western, eastern, and whole of US due to the underestimation of OC in the simulation.

In summary, model results agreed with observations in that the concentrations of all aerosol species of $\mathrm{SO}_{4}^{2-}, \mathrm{NO}_{3}^{-}$, $\mathrm{NH}_{4}^{+}, \mathrm{BC}$, and $\mathrm{OC}$ averaged over the US were higher in $\mathrm{PNA}+$ months than in PNA - months. Relative to the PNAmonths, the average concentration of $\mathrm{PM}_{2.5}$ over the US was higher by about $8.7 \%(12.2 \%)$ based on observed (simulated) concentrations. Furthermore, simulated geographical patterns of the differences in $\mathrm{PM}_{2.5}$ and each aerosol species between the PNA+ and PNA - months were similar to those seen in observations in most areas of the US (except for California), with the largest increases in aerosol concentrations in PNA+ months over and near the eastern Midwest.

\section{Mechanisms for the impact of PNA on aerosol concentrations}

\subsection{The impact of PNA on transboundary transport of aerosols}

The transboundary transport of pollutants to and from the US depends largely on winds in the free troposphere (Liang et al., 2004). Figure 6 shows the horizontal winds at $700 \mathrm{hPa}$ averaged over the winter months of NDJFM of 19862006 and the corresponding differences between PNA+ and PNA - months on the basis of the GEOS-4 meteorological fields. Strong westerlies prevailed over the US in wintertime (Fig. 6a). Relative to the PNA - months, anomalous northeasterlies occurred over a large fraction of US in the PNA+ months. Anomalous anti-cyclonic circulation occurred near the northwestern US and anomalous cyclonic circulation occurred near the southeastern US (Fig. 6b), corresponding to the large positive and negative differences in geopotential height in these two regions (see Fig. S1), respectively.

We also calculate mass fluxes of $\mathrm{PM}_{2.5}$ at the four lateral boundaries (from the surface to $250 \mathrm{hPa}$ ) of the US for different PNA phases (Table 3). The domain of the box to represent the US is $\left(75-120^{\circ} \mathrm{W}, 28-49^{\circ} \mathrm{N}\right)$, as shown in Fig. $6 \mathrm{~b}$. For $\mathrm{PM}_{2.5}$ in wintertime, the inflow from the west boundary and the outflow from the east boundary had the largest absolute values (Table 3). Relative to the PNA- months, 
(a) UV $\left(\mathrm{m} \mathrm{s}^{-1}\right)$ at $700 \mathrm{hPa}$

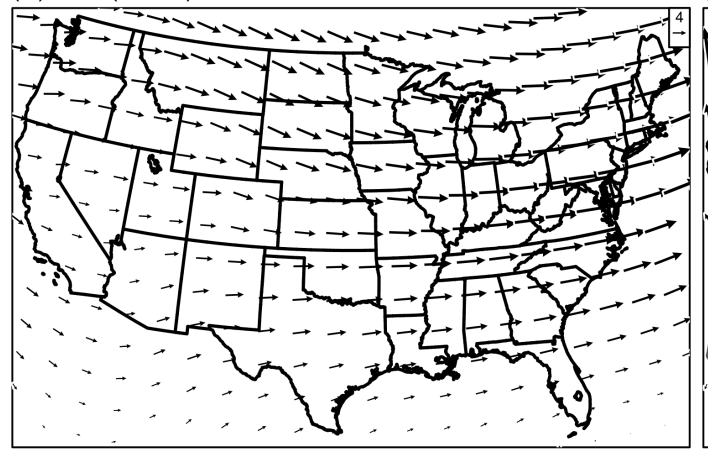

(b) UV $\left(\mathrm{m} \mathrm{s}^{-1}\right)$ Diff. at $700 \mathrm{hPa}$

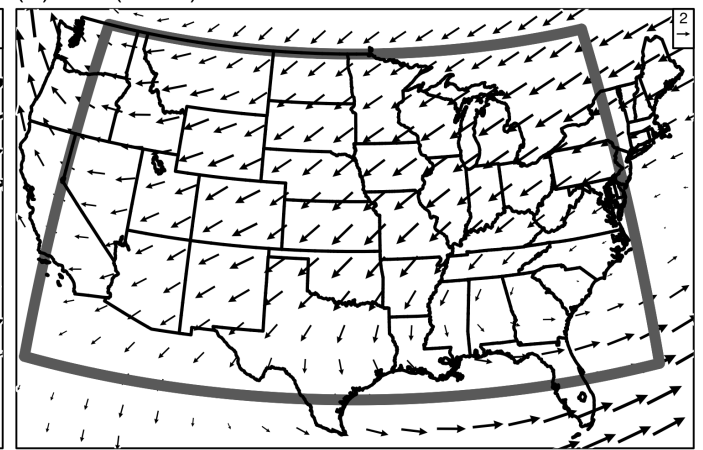

Figure 6. (a) Horizontal winds at $700 \mathrm{hPa}$ averaged over the winter months of NDJFM of 1986-2006, and (b) the corresponding differences between the PNA+ and PNA - months. data sets are from the assimilated GEOS-4 meteorological fields. Also shown in (b) is the domain of $\left(75-120^{\circ} \mathrm{W}, 28-49^{\circ} \mathrm{N}\right)$ for which transboundary mass fluxes of $\mathrm{PM}_{2.5}$ are calculated. See Fig. 2c for the definitions of PNA+ and PNAmonths.

the inflow from the west boundary and the outflow from the east boundary in PNA+ months exhibited reductions of 16.1 and $13.5 \mathrm{~kg} \mathrm{~s}^{-1}$, respectively (Table 3 ). The inflow flux from south boundary decreased by $15.8 \mathrm{~kg} \mathrm{~s}^{-1}$, and the inflow flux from north boundary increased by $31.7 \mathrm{~kg} \mathrm{~s}^{-1}$, leading to a net increase of inflow flux of $13.3 \mathrm{~kg} \mathrm{~s}^{-1}$ in PNA+ months. Therefore, the transboundary transport has an overall effect of increasing $\mathrm{PM}_{2.5}$ aerosols in the US in PNA+ months relative to PNA- months. The relative change in net flux was $9.9 \%((\mathrm{PNA}+$ minus PNA- $) \times 100 \% / \mathrm{PNA}-)$ (Table 3$)$, coinciding well with the enhancement of $12.2 \%$ in surfacelayer $\mathrm{PM}_{2.5}$ concentration averaged over the US (Table 2). Note that because the GEOS-Chem model underestimates $\mathrm{PM}_{2.5}$ concentrations in the western US (Fig. 4b), the net outflow flux from the selected box might have been underestimated, but this should not compromise our conclusions about the relative differences in net flux between PNA + and PNA- phases.

\subsection{Local changes in aerosol concentrations caused by the PNA}

The PNA pattern is also associated with variations in meteorological variables such as temperature (Leathers et al., 1991; Konrad II, 1998; Notaro et al., 2006; Knight et al., 2008; Liu et al., 2015; Ning and Bradley, 2014, 2015), precipitation (Leathers et al., 1991; Henderson and Robinson, 1994; Coleman and Rogers, 2003; Notaro et al., 2006; Archambault et al., 2008; Myoung and Deng, 2009; Ning and Bradley, 2014, 2015; Wise et al., 2015), and humidity (Sheridan, 2003; Coleman and Rogers, 2003; Knight et al., 2008) in US, which are expected to influence aerosol concentrations within the US through chemical reactions, transport, and deposition.

Figure 7 shows the composite differences, between the PNA + and PNA - months, in surface air temperature $(T)$, precipitation rate $(\mathrm{PR})$, relative humidity $(\mathrm{RH})$, surface wind
Table 3. The composite analyses of horizontal mass fluxes $\left(\mathrm{kg} \mathrm{s}^{-1}\right)$ of $\mathrm{PM}_{2.5}$ for the selected box of $\left(75-120^{\circ} \mathrm{W}, 28-49^{\circ} \mathrm{N}\right.$; from the surface to $250 \mathrm{hPa}$ ) in the PNA+ and PNA - months of 19862006. The positive values at the four boundaries indicate eastward or northward transport, and negative values indicate westward or southward transport. The positive (negative) value of net flux indicates the net gain (loss) of $\mathrm{PM}_{2.5}$ in the selected box. All the fluxes are from the GEOS-Chem simulation.

\begin{tabular}{llr}
\hline & Boundaries and total & Mass flux \\
\hline PNA+ & West & 75.0 \\
& East & 233.9 \\
& South & 15.0 \\
& North & -22.9 \\
& Net flux & -120.9 \\
PNA- & West & 91.1 \\
& East & 247.4 \\
& South & 30.8 \\
& North & 8.8 \\
Diff. (PNA+ minus PNA-) & Net flux & West \\
& East & -134.2 \\
& South & -13.1 \\
& North & -15.8 \\
& Net flux & -31.7 \\
& & 13.3 \\
\hline
\end{tabular}

speed (WS), and planetary boundary layer height (PBLH), based on the reanalyzed GEOS-4 data sets. Relative to PNA - months, temperatures were higher by $1-3 \mathrm{~K}$ over the northwestern US and lower by $1-4 \mathrm{~K}$ in the southeastern region. Such geographic distributions of temperature anomalies were attributed to the maritime warm air in the northwestern US accompanied by the enhanced tropospheric geopotential height in North America (Leathers et al., 1991; Sheridan, 2003; Liu et al., 2015; Ning and Bradley, 2015) (see also Fig. S1d) and the more frequent outbreak of cold air in southeastern US accompanied by the depressed geopotential height (Konrad II, 1998; Liu et al., 2015) (see also 
(a) Abs. diff.
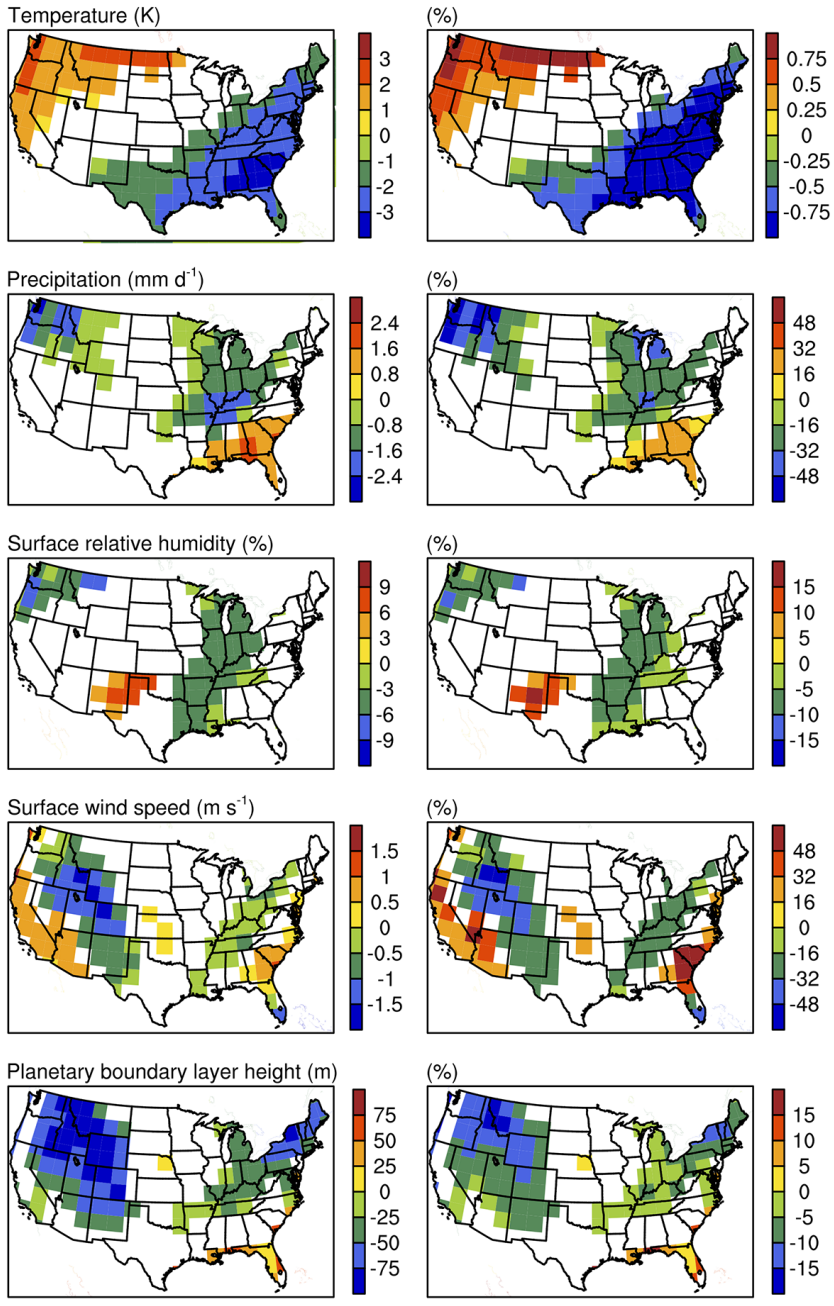

Figure 7. (a) The absolute and (b) relative differences in meteorological parameters between PNA+ and PNA - months. data sets are from the assimilated GEOS-4 meteorological fields. The white spaces in indicate the areas that did not pass the two-tail student $t$ test with $90 \%$ significance level. The seasonal cycles of meteorological variables were removed, similar to the treatment for observations in Fig. 3. See Fig. 2c for the definitions of PNA+ and PNA- months.

Fig. S1d). The differences in precipitation between PNA+ and PNA - months reached -1.6 to $-2.4 \mathrm{~mm} \mathrm{day}^{-1}(-32$ to $-48 \%$ ) over and near the eastern Midwest, -2.4 to $-3.2 \mathrm{~mm} \mathrm{day}^{-1}(-48$ to $-64 \%)$ in the northwestern US, and $1.6-2.4 \mathrm{~mm} \mathrm{day}^{-1}(16-32 \%)$ in the southeastern US. These effects of PNA on precipitation were similar to those obtained from wintertime station data by Leathers et al. (1991), Coleman and Rogers (2003), and Wise et al. (2015). With respect to RH, the values in the eastern US were generally lower in the PNA+ months than in PNA- months, as a result of the reduced moisture flux from the Gulf of Mexico to the eastern US (Coleman and Rogers, 2003), where RH showed maximum reduction of -3 to $-9 \%$. The enhancement of $\mathrm{RH}$ of up to $6-9 \%$ in Texas, Oklahoma, and New Mexico was due to the anomalous easterlies over the south central US (see Fig. 7), which diminished the influence of the dry air from the deserts of the southwestern US and northwestern Mexico in PNA+ months (Sheridan, 2003). The surface WS showed reductions in PNA+ months relative to PNA- months in two regions, one was the belt region along the Rocky Mountains from the northwestern US to Texas (with the maximum reductions of $1.5-2.0 \mathrm{~m} \mathrm{~s}^{-1}(48-64 \%)$ ) and the other region, with a northeast-southwest orientation, was from Ohio to Louisiana (with maximum reductions of $0.5-1.0 \mathrm{~m} \mathrm{~s}^{-1}$ (16$32 \%)$ ). The differences in PBLH between PNA+ and PNAmonths were statistically significant in the western US and in the belt region from the northeastern US to the eastern Midwest, with maximum reductions in PBLH of 75-100 m (15$20 \%)$ and $75-100 \mathrm{~m}(10-15 \%)$, respectively. The changes of PBLH were possibly associated with the frequent outbreak of cold air in the US in PNA+ phases (Leathers et al., 1991; Archambault et al., 2010), which induced cool air at the surface and clouds over the intermountain and the eastern Midwest regions (Sheridan, 2003).

The comparisons of Fig. 5b with Fig. 7a indicate that the increases in $\mathrm{PM}_{2.5}$ concentrations over and near the eastern Midwest in PNA+ months relative to the PNA- months can be attributed to the decreases in PR, WS, and PBLH in these locations, since the changes in these three variables depressed wet deposition, local horizontal diffusion, and vertical diffusion of the surface aerosols, respectively. The increases in $\mathrm{SO}_{4}^{2-}$ in the western US (Fig. 5b) corresponded to the decreases in PR and PBLH and the increased temperature. The increases in temperature enhance chemical reaction rates (Aw and Kleeman, 2003; Dawson et al., 2007; Kleeman, 2008). In the eastern US, although PR, WS, and PBLH decreased over and near the eastern Midwest, the cooling in the eastern US might have offset the effects by PR, WS, and $\mathrm{PBLH}$, inducing practically no changes in $\mathrm{SO}_{4}^{2-}$ in the eastern US. The large increases in $\mathrm{NO}_{3}^{-}$and $\mathrm{NH}_{4}^{+}$in the southeastern US (Fig. 5b) can be attributed to the reduced surface temperature, which was favorable to the wintertime formation of $\mathrm{NO}_{3}^{-}$and $\mathrm{NH}_{4}^{+}$(Dawson et al., 2007). The differences in concentrations of $\mathrm{OC}$ and $\mathrm{BC}$ between PNA+ and PNAcorresponded well with the reduced PR, WS, and PBLH.

In order to quantify the impacts of anomalies in meteorological parameters driven by PNA on concentrations of different aerosol species, the pattern correlation coefficients (PCC; http://glossary.ametsoc.org/wiki/Pattern_correlation) are calculated and shown in Table 4. These pattern correlation coefficients denote the relationship between the geographical distribution of anomalies of each of $T, \mathrm{PR}, \mathrm{RH}$, WS, and PBLH (Fig. 7b) and that of the differences in concentration of each aerosol species between PNA+ and PNA- months (Fig. 5c). As shown in Table 4, over the whole US, the PNA influenced $\mathrm{SO}_{4}^{2-}$ concentrations mainly 
Table 4. The pattern correlation coefficients between the composite differences in aerosol concentrations (Fig. 5c) and the corresponding composite differences in meteorological parameters (Fig. 7b).

\begin{tabular}{lrrrrrr}
\hline & $\mathrm{PM}_{2.5}$ & \multicolumn{1}{c}{$\mathrm{SO}_{4}^{2-}$} & $\mathrm{NO}_{3}^{-}$ & $\mathrm{NH}_{4}^{+}$ & $\mathrm{OC}$ & $\mathrm{BC}$ \\
\hline$T$ & -0.13 & $0.26^{*}$ & $-0.59^{*}$ & $-0.22^{*}$ & 0.07 & -0.16 \\
$\mathrm{PR}$ & $-0.44^{*}$ & $-0.38^{*}$ & 0.04 & $-0.42^{*}$ & $-0.63^{*}$ & $-0.50^{*}$ \\
$\mathrm{RH}$ & -0.08 & -0.05 & -0.02 & 0.12 & $-0.32^{*}$ & $-0.36^{*}$ \\
$\mathrm{WS}$ & $-0.27^{*}$ & -0.1 & $-0.22^{*}$ & $-0.27^{*}$ & $-0.28^{*}$ & $-0.24^{*}$ \\
PBLH & $-0.61^{*}$ & $-0.43^{*}$ & $-0.32^{*}$ & $-0.61^{*}$ & $-0.60^{*}$ & $-0.55^{*}$ \\
\hline
\end{tabular}

The ${ }^{*}$ denotes the correlations that have passed the two-tail $t$ test with $95 \%$ confidence level.

through changes in PBLH, PR, and T, with the highest PCC values of $-0.43,-0.38$, and +0.26 , respectively. For $\mathrm{NO}_{3}^{-}$, the PNA-induced variations in temperature had a strong negative correlation $(\mathrm{PCC}=-0.59)$ with the PNA-induced differences in concentrations, indicating that surface temperature was the dominant meteorological factor to influence $\mathrm{NO}_{3}^{-}$concentrations. For $\mathrm{NH}_{4}^{+}, \mathrm{OC}$, and $\mathrm{BC}, \mathrm{PR}$ and $\mathrm{PBLH}$ were the two variables that had the largest negative PCC values (Table 4).

\section{Conclusions}

This study examined the impacts of monthly variation in the PNA phase on wintertime surface-layer aerosol concentrations in the US by the analyses of EPA-AQS observations over 1999-2013 and model results for 1986-2006 from the global chemical transport model GEOS-Chem.

The composite analyses on the EPA-AQS observations showed that the average concentrations of $\mathrm{PM}_{2.5}, \mathrm{SO}_{4}^{2-}$, $\mathrm{NO}_{3}^{-}, \mathrm{NH}_{4}^{+}$, OC, and $\mathrm{BC}$ aerosols over the US were higher in the PNA+ months than in the PNA- months by $1.0 \mu \mathrm{g} \mathrm{m}^{-3}(8.7 \%), 0.01 \mu \mathrm{g} \mathrm{m}^{-3}(0.5 \%), 0.3 \mu \mathrm{g} \mathrm{m}^{-3}$ $(29.1 \%), 0.1 \mu \mathrm{g} \mathrm{m}^{-3}$ (11.9\%), $0.6 \mu \mathrm{g} \mathrm{m}^{-3}$ (13.5\%), and $0.2 \mu \mathrm{g} \mathrm{m}^{-3}(27.8 \%)$, respectively. Regionally, the observed $\mathrm{PM}_{2.5}$ concentrations were higher by $3-5 \mu \mathrm{g} \mathrm{m}^{-3}$ (40-80\%) over the Midwest, and by $7-9 \mu \mathrm{g} \mathrm{m}^{-3}(80-100 \%)$ around Salt Lake, as the concentrations in PNA+ months were compared to those in PNA- months.

The impacts of PNA phase on aerosol concentrations were reproduced fairly well by the GEOS-Chem simulation with fixed anthropogenic emissions (the variations of aerosols concentrations were driven by changes in meteorological fields alone). Concentrations of $\mathrm{SO}_{4}^{2-}, \mathrm{NO}_{3}^{-}, \mathrm{NH}_{4}^{+}, \mathrm{BC}$, and OC averaged over the US were simulated to be higher in the PNA+ months than in PNA- months. The average concentration of $\mathrm{PM}_{2.5}$ over the US was simulated to be $12.2 \%$ higher in the PNA+ months relative to the PNA - months, in close agreement with the observations. Simulated geographical patterns of the differences in $\mathrm{PM}_{2.5}$ and each aerosol species between the PNA+ and PNA- months were similar to those seen in observations. The largest increases in aerosol concentrations in the PNA+ months were simulated to be over and near the eastern Midwest, but the model results showed small PNA-induced changes in aerosol concentrations in the western US.

The mechanisms for the impacts of PNA on aerosol concentrations were examined. The transboundary transport was found to have an overall effect of increasing $\mathrm{PM}_{2.5}$ aerosols in the US in the PNA+ months relative to PNA- months. Compared to the PNA- months, anomalous northeasterlies occurred over a large fraction of US, which led to a net increase in inflow flux of $\mathrm{PM}_{2.5}$ of $13.3 \mathrm{Kg} \mathrm{s}^{-1}$ in PNA+ months. Regionally within the US, the PNA influenced aerosol concentrations through changes in precipitation rate (PR), planetary boundary layer height (PBLH), surface wind speed (WS), surface air temperature $(T)$, and relative humidity $(\mathrm{RH})$, as represented by the pattern correlation coefficients (PCCs). The PNA influenced $\mathrm{SO}_{4}^{2-}$ concentration mainly through changes PBLH, PR, and T, with the highest PCC values of $-0.43,-0.38$, and +0.26 , respectively. For $\mathrm{NO}_{3}^{-}$, the PNA-induced variations in temperature had a strong negative correlation $(\mathrm{PCC}=-0.59)$ with the PNA-induced differences in concentrations. For $\mathrm{NH}_{4}^{+}$, $\mathrm{OC}$, and $\mathrm{BC}, \mathrm{PR}$ and $\mathrm{PBLH}$ were the two variables that had the largest negative PCC values. It should be noted that, the PCC values only statistically present the relationship between meteorological parameters and aerosol concentrations in the US. More in-depth understanding of the impact of PNA phase on aerosol concentrations should be carried out on the basis of physical and chemical processes.

Conclusions from this study have important implications for air quality in the US. Leathers and Palecki (1992) showed that the PNAI were generally low in 1947-1957 but consistently high in 1958-1987. The PNAI during 19482010 exhibited an increasing trend for positive phases and a decreasing trend for negative phases (Liu et al., 2015; Ning and Bradley, 2015; http://research.jisao.washington. edu/data_sets/pna/\#djf), indicating that wintertime particulate matter pollution in most areas of US deteriorated due to variations in PNA phase alone. Climate models projected that positive PNA phases would increase in the future because of the global warming (Kachi and Nitta, 1997; Müller and Roeckner, 2008; Zhou, 2014). Therefore, the trend in PNA pattern underlies the necessity of strict emission reduction strategies for greenhouse gases, aerosols, and aerosol precursors.

\section{The Supplement related to this article is available online at doi:10.5194/acp-16-4927-2016-supplement.}

Acknowledgements. This work was supported by the $\mathrm{Na}-$ tional Basic Research Program of China (973 program, grant 2014CB441202), the Strategic Priority Research Program of the Chinese Academy of Sciences Strategic Priority Research Program 
grant no. XDA05100503, and the National Natural Science Foundation of China under grants 91544219, 41475137, and 41321064. We thank the anonymous reviewers for helpful suggestions to improve the quality of the paper.

Edited by: H. Wang

\section{References}

Alexander, B., Park, R. J., Jacob, D. J., Li, Q. B., Yantosca, R. M., Savarino, J., Lee, C. C. W., and Thiemens, M. H.: Sulfate formation in sea-salt aerosols: Constraints from oxygen isotopes, J. Geophys. Res., 110, D10307, doi:10.1029/2004JD005659, 2005.

Allen, R. J., Landuyt, W., and Rumbold, S. T.: An increase in aerosol burden and radiative effects in a warmer world, Nature Climate Change, 6, 269-274, doi:10.1038/nclimate2827, 2015.

Alston, E. J., Sokolik, I. N., and Kalashnikova, O. V.: Characterization of atmospheric aerosol in the US Southeast from ground- and space-based measurements over the past decade, Atmos. Meas. Tech., 5, 1667-1682, doi:10.5194/amt-5-1667-2012, 2012.

Archambault, H. M., Bosart, L. F., Keyser, D., and Aiyyer, A. R.: Influence of Large-Scale Flow Regimes on Cool-Season Precipitation in the Northeastern United States, Mon. Weather Rev., 136, 2945-2963, doi:10.1175/2007MWR2308.1, 2008.

Archambault, H. M., Keyser, D., and Bosart, L. F.: Relationships between Large-Scale Regime Transitions and Major Cool-Season Precipitation Events in the Northeastern United States, Mon. Weather Rev., 138, 3454-3473, doi:10.1175/2010MWR3362.1, 2010.

Athanasiadis, P. J. and Ambaum, M. H. P.: Linear Contributions of Different Time Scales to Teleconnectivity, J. Climate, 22, 37203728, doi:10.1175/2009JCLI2707.1, 2009.

Aw, J. and Kleeman, M. J.: Evaluating the first-order effect of intraannual temperature variability on urban air pollution, J. Geophys. Res., 108, 4365, doi:10.1029/2002JD002688, 2003.

Bauer, S. E., Koch, D., Unger, N., Metzger, S. M., Shindell, D. T., and Streets, D. G.: Nitrate aerosols today and in 2030: a global simulation including aerosols and tropospheric ozone, Atmos. Chem. Phys., 7, 5043-5059, doi:10.5194/acp-7-5043-2007, 2007.

Bey, I., Jacob, D. J., Yantosca, R. M., Logan, J. A., Field, B. D., Fiore, A. M., Li, Q., Liu, H. Y., Mickley, L. J., and Schultz, M. G.: Global modeling of tropospheric chemistry with assimilated meteorology: Model description and evaluation, J. Geophys. Res., 106, 23073, doi:10.1029/2001JD000807, 2001.

Blackmon, M. L., Lee, Y.-H., and Wallace, J. M.: Horizontal Structure of $500 \mathrm{mb}$ Height Fluctuations with Long, Intermediate and Short Time Scales, J. Atmos. Sci., 41, 961-980, doi:10.1175/1520-0469(1984)041<0961:HSOMHF>2.0.CO;2, 1984.

Cakmur, R. V., Miller, R. L., and Tegen, I.: A comparison of seasonal and interannual variability of soil dust aerosols over the Atlantic Ocean as inferred by the TOMS AI and AVHRR AOT retrievals, J. Geophys. Res., 106, 18287, doi:10.1029/2000JD900525, 2001.

Coleman, J. S. M. and Rogers, J. C.: Ohio River Valley Winter Moisture Conditions Associated with the Pacific-North
American Teleconnection Pattern, J. Climate, 16, 969-981, doi:10.1175/1520-0442(2003)016<0969:ORVWMC>2.0.CO;2, 2003.

Dawson, J. P., Adams, P. J., and Pandis, S. N.: Sensitivity of $\mathrm{PM}_{2.5}$ to climate in the Eastern US: a modeling case study, Atmos. Chem. Phys., 7, 4295-4309, doi:10.5194/acp-7-4295-2007, 2007.

Day, M. C. and Pandis, S. N.: Predicted changes in summertime organic aerosol concentrations due to increased temperatures, Atmos. Environ., 45, 6546-6556, doi:10.1016/j.atmosenv.2011.08.028, 2011.

Di Pierro, M., Jaeglé, L., and Anderson, T. L.: Satellite observations of aerosol transport from East Asia to the Arctic: three case studies, Atmos. Chem. Phys., 11, 2225-2243, doi:10.5194/acp11-2225-2011, 2011.

Drury, E., Jacob, D. J., Spurr, R. J. D., Wang, J., Shinozuka, Y., Anderson, B. E., Clarke, A. D., Dibb, J., McNaughton, C., and Weber, R.: Synthesis of satellite (MODIS), aircraft (ICARTT), and surface (IMPROVE, EPA-AQS, AERONET) aerosol observations over eastern North America to improve MODIS aerosol retrievals and constrain surface aerosol concentrations and sources, J. Geophys. Res., 115, D14204, doi:10.1029/2009JD012629, 2010.

Duncan, B. N., Martin, R. V., Staudt, A. C., Yevich, R., and Logan, J. A.: Interannual and seasonal variability of biomass burning emissions constrained by satellite observations, J. Geophys. Res., 108, 4100, doi:10.1029/2002JD002378, 2003.

Dutkiewicz, V. A., Das, M., and Husain, L.: The relationship between regional $\mathrm{SO}_{2}$ emissions and downwind aerosol sulfate concentrations in the northeastern US, Atmos. Environ., 34, 1821-1832, doi:10.1016/S1352-2310(99)00334-9, 2000.

Fairlie, D. T., Jacob, D. J., and Park, R. J.: The impact of transpacific transport of mineral dust in the United States, Atmos. Environ. 41, 1251-1266, doi:10.1016/j.atmosenv.2006.09.048, 2007.

Feldstein, S. B.: Fundamental mechanisms of the growth and decay of the PNA teleconnection pattern, Q. J. Roy. Meteor. Soc., 128, 775-796, doi:10.1256/0035900021643683, 2002.

Feldstein, S. B.: The dynamics of NAO teleconnection pattern growth and decay, Q. J. Roy. Meteor. Soc., 129, 901-924, doi:10.1256/qj.02.76, 2003.

Fu, T.-M., Jacob, D. J., and Heald, C. L.: Aqueous-phase reactive uptake of dicarbonyls as a source of organic aerosol over eastern North America, Atmos. Environ., 43, 1814-1822, doi:10.1016/j.atmosenv.2008.12.029, 2009.

Generoso, S., Bréon, F.-M., Balkanski, Y., Boucher, O., and Schulz, M.: Improving the seasonal cycle and interannual variations of biomass burning aerosol sources, Atmos. Chem. Phys., 3, $1211-$ 1222, doi:10.5194/acp-3-1211-2003, 2003.

Giglio, L., van der Werf, G. R., Randerson, J. T., Collatz, G. J., and Kasibhatla, P.: Global estimation of burned area using MODIS active fire observations, Atmos. Chem. Phys., 6, 957974, doi:10.5194/acp-6-957-2006, 2006.

Gong, S. L., Zhang, X. Y., Zhao, T. L., Zhang, X. B., Barrie, L. A., McKendry, I. G., and Zhao, C. S.: A Simulated Climatology of Asian Dust Aerosol and Its Trans-Pacific Transport. Part II: Interannual Variability and Climate Connections, J. Climate, 19, 104-122, doi:10.1175/JCLI3606.1, 2006.

Guenther, A., Karl, T., Harley, P., Wiedinmyer, C., Palmer, P. I., and Geron, C.: Estimates of global terrestrial isoprene emissions 
using MEGAN (Model of Emissions of Gases and Aerosols from Nature), Atmos. Chem. Phys., 6, 3181-3210, doi:10.5194/acp-63181-2006, 2006.

Hack, J. J.: Parameterization of moist convection in the National Center for Atmospheric Research community climate model (CCM2), J. Geophys. Res., 99, 5551, doi:10.1029/93JD03478, 1994.

Hand, J. L., Schichtel, B. A., Malm, W. C., and Pitchford, M. L.: Particulate sulfate ion concentration and $\mathrm{SO}_{2}$ emission trends in the United States from the early 1990s through 2010, Atmos. Chem. Phys., 12, 10353-10365, doi:10.5194/acp-1210353-2012, 2012a.

Hand, J. L., Schichtel, B. A., Pitchford, M., Malm, W. C., and Frank, N. H.: Seasonal composition of remote and urban fine particulate matter in the United States, J. Geophys. Res., 117, D05209, doi:10.1029/2011JD017122, 2012b.

Hand, J. L., Schichtel, B. A., Malm, W. C., Pitchford, M., and Frank, N. H.: Spatial and seasonal patterns in urban influence on regional concentrations of speciated aerosols across the United States, J. Geophys. Res.-Atmos., 119, 12832-12849, doi:10.1002/2014JD022328, 2014.

Heald, C. L., Jacob, D. J., Park, R. J., Alexander, B., Fairlie, T. D., Yantosca, R. M., and Chu, D. A.: Transpacific transport of Asian anthropogenic aerosols and its impact on surface air quality in the United States, J. Geophys. Res.-Atmos., 111, 1-13, doi:10.1029/2005JD006847, 2006.

Heald, C. L., Henze, D. K., Horowitz, L. W., Feddema, J., Lamarque, J.-F., Guenther, A., Hess, P. G., Vitt, F., Seinfeld, J. H., Goldstein, A. H., and Fung, I.: Predicted change in global secondary organic aerosol concentrations in response to future climate, emissions, and land use change, J. Geophys. Res.-Atmos., 113, D05211, doi:10.1029/2007JD009092, 2008.

Heald, C. L., Collett Jr., J. L., Lee, T., Benedict, K. B., Schwandner, F. M., Li, Y., Clarisse, L., Hurtmans, D. R., Van Damme, M., Clerbaux, C., Coheur, P.-F., Philip, S., Martin, R. V., and Pye, H. O. T.: Atmospheric ammonia and particulate inorganic nitrogen over the United States, Atmos. Chem. Phys., 12, 10295-10312, doi:10.5194/acp-12-10295-2012, 2012.

Henderson, K. G. and Robinson, P. J.: Relationships between the pacific/north american teleconnection patterns and precipitation events in the south-eastern USA, Int. J. Climatol., 14, 307-323, doi:10.1002/joc.3370140305, 1994.

Holmes, C. D., Prather, M. J., Søvde, O. A., and Myhre, G.: Future methane, hydroxyl, and their uncertainties: key climate and emission parameters for future predictions, Atmos. Chem. Phys., 13, 285-302, doi:10.5194/acp-13-285-2013, 2013.

IPCC: Climate Change 2013 The Physical Science Basis: Working Group I Contribution to the Fifth Assessment Report of the Intergovernmental Panel on Climate Change, 1st Edn., Cambridge University Press, New York, available at: http://www.climatechange2013.org/images/report/WG1AR5_ ALL_FINAL.pdf (last access: 9 April 2016), 2015.

Jacob, D. J. and Winner, D. A.: Effect of climate change on air quality, Atmos. Environ., 43, 51-63, doi:10.1016/j.atmosenv.2008.09.051, 2009.

Jerez, S., Jimenez-Guerrero, P., Montávez, J. P., and Trigo, R. M.: Impact of the North Atlantic Oscillation on European aerosol ground levels through local processes: a seasonal model-based assessment using fixed anthropogenic emissions, Atmos. Chem. Phys., 13, 11195-11207, doi:10.5194/acp-13-11195-2013, 2013.

Juda-Rezler, K., Reizer, M., Huszar, P., Krüger, B., Zanis, P., Syrakov, D., Katragkou, E., Trapp, W., Melas, D., Chervenkov, H., Tegoulias, I., and Halenka, T.: Modelling the effects of climate change on air quality over Central and Eastern Europe: concept, evaluation and projections, Clim. Res., 53, 179-203, doi:10.3354/cr01072, 2012.

Kachi, M. and Nitta, T.: Decadal variations of the global atmosphere-ocean system, J. Meteorol. Soc. Jpn., 75, 657-675, 1997.

Kleeman, M. J.: A preliminary assessment of the sensitivity of air quality in California to global change, Climatic Change, 87, 273 292, doi:10.1007/s10584-007-9351-3, 2008.

Knight, D. B., Davis, R. E., Sheridan, S. C., Hondula, D. M., Sitka, L. J., Deaton, M., Lee, T. R., Gawtry, S. D., Stenger, P. J., Mazzei, F., and Kenny, B. P.: Increasing frequencies of warm and humid air masses over the conterminous United States from 1948 to 2005, Geophys. Res. Lett., 35, L10702, doi:10.1029/2008GL033697, 2008.

Konrad II, C. E.: Persistent planetary scale circulation patterns and their relationship with cold air outbreak activity over the Eastern United States, Int. J. Climatol., 18, 12091221, doi:10.1002/(SICI)1097-0088(199809)18:11<1209::AIDJOC301>3.0.CO;2-K, 1998.

Lam, Y. F., Fu, J. S., Wu, S., and Mickley, L. J.: Impacts of future climate change and effects of biogenic emissions on surface ozone and particulate matter concentrations in the United States, Atmos. Chem. Phys., 11, 4789-4806, doi:10.5194/acp-11-47892011, 2011.

Leathers, D. J. and Palecki, M. A.: The Pacific/North American Teleconnection Pattern and United States Climate. Part II: Temporal Characteristics and Index Specification, J. Climate, 5, 707-716, doi:10.1175/1520 0442(1992)005<0707:TPATPA>2.0.CO;2, 1992.

Leathers, D. J., Yarnal, B., and Palecki, M. A.: The Pacific/North American Teleconnection Pattern and United States Climate. Part I: Regional Temperature and Precipitation Associations, J. Climate, 4, 517-528, doi:10.1175/15200442(1991)004<0517:TPATPA>2.0.CO;2, 1991.

Leibensperger, E. M., Mickley, L. J., Jacob, D. J., and Barrett, S. R. H.: Intercontinental influence of $\mathrm{NO}_{x}$ and $\mathrm{CO}$ emissions on particulate matter air quality, Atmos. Environ., 45, 3318-3324, doi:10.1016/j.atmosenv.2011.02.023, 2011.

Li, J., Carlson, B. E., and Lacis, A. A.: Application of spectral analysis techniques in the intercomparison of aerosol data: 1. An EOF approach to analyze the spatial-temporal variability of aerosol optical depth using multiple remote sensing data sets, J. Geophys. Res.-Atmos., 118, 8640-8648, doi:10.1002/jgrd.50686, 2013.

Liang, Q., Jaeglé, L., Jaffe, D. A., Weiss-Penzias, P., Heckman, A., and Snow, J. A.: Long-range transport of Asian pollution to the northeast Pacific: Seasonal variations and transport pathways of carbon monoxide, J. Geophys. Res.-Atmos., 109, 1-16, doi:10.1029/2003JD004402, 2004.

Liang, Q., Jaeglé, L., and Wallace, J. M.: Meteorological indices for Asian outflow and transpacific transport on daily to interannual timescales, J. Geophys. Res., 110, D18308, doi:10.1029/2005JD005788, 2005. 
Liao, H., Chen, W. T., and Seinfeld, J. H.: Role of climate change in global predictions of future tropospheric ozone and aerosols, J. Geophys. Res.-Atmos., 111, 1-18, doi:10.1029/2005JD006852, 2006.

Liao, H., Henze, D. K., Seinfeld, J. H., Wu, S., and Mickley, L. J.: Biogenic secondary organic aerosol over the United States: Comparison of climatological simulations with observations, J. Geophys. Res., 112, D06201, doi:10.1029/2006JD007813, 2007.

Lin, S.-J. and Rood, R. B.: Multidimensional FluxForm Semi-Lagrangian Transport Schemes, Mon. Weather Rev., 124, 2046-2070, doi:10.1175/15200493(1996)124<2046:MFFSLT>2.0.CO;2, 1996.

Liu, Y., Park, R. J., Jacob, D. J., Li, Q., Kilaru, V., and Sarnat, J. A.: Mapping annual mean ground-level $\mathrm{PM}_{2.5}$ concentrations using Multiangle Imaging Spectroradiometer aerosol optical thickness over the contiguous United States, J. Geophys. Res., 109, D22206, doi:10.1029/2004JD005025, 2004.

Liu, Y., Liu, J., and Tao, S.: Interannual variability of summertime aerosol optical depth over East Asia during 2000-2011: a potential influence from El Niño Southern Oscillation, Environ. Res. Lett., 8, 044034, doi:10.1088/1748-9326/8/4/044034, 2013.

Liu, Z., Jian, Z., Yoshimura, K., Buenning, N. H., Poulsen, C. J., and Bowen, G. J.: Recent contrasting winter temperature changes over North America linked to enhanced positive Pacific-North American pattern, Geophys. Res. Lett., 42, 1-8, doi:10.1002/2015GL065656, 2015.

Liu, H.-Y., Jacob, D. J., Bey, I., and Yantosca, R. M.: Constraints $\mathrm{Pb}-210$ and $\mathrm{Be}-7$ on Wet Deposition and Transport in a Global Three-Dimensional Chemical Tracer Model Driven by Assimilated Meteorological Fields, J. Geophys. Res.-Atmos., 106, doi:10.1029/2000JD900839, 2001.

Mahowald, N., Luo, C., del Corral, J., and Zender, C. S.: Interannual variability in atmospheric mineral aerosols from a 22-year model simulation and observational data, J. Geophys. Res., 108, 4352, doi:10.1029/2002JD002821, 2003.

Malm, W. C.: Spatial and monthly trends in speciated fine particle concentration in the United States, J. Geophys. Res., 109, D03306, doi:10.1029/2003JD003739, 2004.

Malm, W. C., Schichtel, B. A., and Pitchford, M. L.: Uncertainties in $\mathrm{PM}_{2.5}$ Gravimetric and Speciation Measurements and What We Can Learn from Them, J. Air Waste Manage., 61, 11311149, doi:10.1080/10473289.2011.603998, 2011

Markakis, K., Valari, M., Perrussel, O., Sanchez, O., and Honore, C.: Climate-forced air-quality modeling at the urban scale: sensitivity to model resolution, emissions and meteorology, Atmos. Chem. Phys., 15, 7703-7723, doi:10.5194/acp-15-7703-2015, 2015.

Megaritis, A. G., Fountoukis, C., Charalampidis, P. E., Denier van der Gon, H. A. C., Pilinis, C., and Pandis, S. N.: Linking climate and air quality over Europe: effects of meteorology on $\mathrm{PM}_{2.5}$ concentrations, Atmos. Chem. Phys., 14, 10283-10298, doi:10.5194/acp-14-10283-2014, 2014.

Mijling, B., van der A, R. J., and Zhang, Q.: Regional nitrogen oxides emission trends in East Asia observed from space, Atmos. Chem. Phys., 13, 12003-12012, doi:10.5194/acp-1312003-2013, 2013.

Moulin, C. and Lambert, C. E., Dulac, F., and Dayan, U.: Control of atmospheric export of dust from North Africa by the North Atlantic Oscillation, Nature, 387, 691-694, 1997.
$\mathrm{Mu}, \mathrm{Q}$. and Liao, H.: Simulation of the interannual variations of aerosols in China: role of variations in meteorological parameters, Atmos. Chem. Phys., 14, 9597-9612, doi:10.5194/acp-149597-2014, 2014.

Müller, W. A. and Roeckner, E.: ENSO teleconnections in projections of future climate in ECHAM5/MPI-OM, Clim. Dynam., 31, 533-549, doi:10.1007/s00382-007-0357-3, 2008.

Murray, L. T., Jacob, D. J., Logan, J. A., Hudman, R. C., and Koshak, W. J.: Optimized regional and interannual variability of lightning in a global chemical transport model constrained by LIS/OTD satellite data, J. Geophys. Res.-Atmos., 117, D20307, doi:10.1029/2012JD017934, 2012.

Myoung, B. and Deng, Y.: Interannual Variability of the Cyclonic Activity along the U.S. Pacific Coast: Influences on the Characteristics of Winter Precipitation in the Western United States, J. Climate, 22, 5732-5747, doi:10.1175/2009JCLI2889.1, 2009.

Ning, L. and Bradley, R. S.: Winter precipitation variability and corresponding teleconnections over the northeastern United States, J. Geophys. Res.-Atmos., 119, 7931-7945, doi:10.1002/2014JD021591, 2014.

Ning, L. and Bradley, R. S.: Winter Climate Extremes over the Northeastern United States and Southeastern Canada and Teleconnections with Large-Scale Modes of Climate Variability, J. Climate, 28, 2475-2493, doi:10.1175/JCLI-D-13-00750.1, 2015.

Notaro, M., Wang, W.-C., and Gong, W.: Model and Observational Analysis of the Northeast U.S. Regional Climate and Its Relationship to the PNA and NAO Patterns during Early Winter, Mon. Weather Rev., 134, 3479-3505, doi:10.1175/MWR3234.1, 2006.

Park, R. J., Jacob, D. J., Chin, M., and Martin, R. V.: Sources of carbonaceous aerosols over the United States and implications for natural visibility, J. Geophys. Res., 108, 4355, doi:10.1029/2002JD003190, 2003.

Park, R. J., Jacob, D. J., Field, B. D., Yantosca, R. M., and Chin, M.: Natural and transboundary pollution influences on sulfate-nitrate-ammonium aerosols in the United States: Implications for policy, J. Geophys. Res., 109, D15204, doi:10.1029/2003JD004473, 2004.

Park, R. J., Jacob, D. J., Palmer, P. I., Clarke, A. D., Weber, R. J., Zondlo, M. A., Eisele, F. L., Bandy, A. R., Thornton, D. C., Sachse, G. W., and Bond, T. C.: Export efficiency of black carbon aerosol in continental outflow: Global implications, J. Geophys. Res.-Atmos., 110, 1-7, doi:10.1029/2004JD005432, 2005.

Park, R. J., Jacob, D. J., Kumar, N., and Yantosca, R. M.: Regional visibility statistics in the United States: Natural and transboundary pollution influences, and implications for the Regional Haze Rule, Atmos. Environ., 40, 5405-5423, doi:10.1016/j.atmosenv.2006.04.059, 2006.

Porter, W. C., Heald, C. L., Cooley, D., and Russell, B.: Investigating the observed sensitivities of air-quality extremes to meteorological drivers via quantile regression, Atmos. Chem. Phys., 15, 10349-10366, doi:10.5194/acp-15-10349-2015, 2015.

Prather, M., Holmes, C., and Hsu, J.: Reactive greenhouse gas scenarios: Systematic exploration of uncertainties and the role of atmospheric chemistry, Geophys. Res. Lett., 39, L09803, doi:10.1029/2012GL051440, 2012.

Pye, H. O. T., Liao, H., Wu, S., Mickley, L. J., Jacob, D. J., Henze, D. K., and Seinfeld, J. H.: Effect of changes in climate and emissions on future sulfate-nitrate-ammonium aerosol 
levels in the United States, J. Geophys. Res., 114, D01205, doi:10.1029/2008JD010701, 2009.

Qian, B., Corte-Real, J., and Xu, H.: Is the North Atlantic Oscillation the most important atmospheric pattern for precipitation in Europe?, J. Geophys. Res., 105, 11901, doi:10.1029/2000JD900102, 2000.

Rattigan, O. V., Felton, H. D., Bae, M.-S., Schwab, J. J., and Demerjian, K. L.: Comparison of long-term $\mathrm{PM}_{2.5}$ carbon measurements at an urban and rural location in New York, Atmos. Environ., 45, 3228-3236, doi:10.1016/j.atmosenv.2011.03.048, 2011.

Redmond, K. T. and Koch, R. W.: Surface Climate and Streamflow Variability in the Western United States and Their Relationship to Large-Scale Circulation Indices, Water Resour. Res., 27, 23812399, doi:10.1029/91WR00690, 1991.

Sauvage, B., Martin, R. V., van Donkelaar, A., Liu, X., Chance, K., Jaeglé, L., Palmer, P. I., Wu, S., and Fu, T.-M.: Remote sensed and in situ constraints on processes affecting tropical tropospheric ozone, Atmos. Chem. Phys., 7, 815-838, doi:10.5194/acp-7-815-2007, 2007.

Sheridan, S. C.: North American weather-type frequency and teleconnection indices, Int. J. Climatol., 23, 27-45, doi:10.1002/joc.863, 2003.

Singh, A. and Palazoglu, A.: Climatic variability and its influence on ozone and PM pollution in 6 non-attainment regions in the United States, Atmos. Environ., 51, 212-224, doi:10.1016/j.atmosenv.2012.01.020, 2012.

Tai, A. P. K., Mickley, L. J., and Jacob, D. J.: Correlations between fine particulate matter $\left(\mathrm{PM}_{2.5}\right)$ and meteorological variables in the United States: Implications for the sensitivity of $\mathrm{PM}_{2.5}$ to climate change, Atmos. Environ., 44, 3976-3984, doi:10.1016/j.atmosenv.2010.06.060, 2010.

Tai, A. P. K., Mickley, L. J., Jacob, D. J., Leibensperger, E. M., Zhang, L., Fisher, J. A., and Pye, H. O. T.: Meteorological modes of variability for fine particulate matter $\left(\mathrm{PM}_{2.5}\right)$ air quality in the United States: implications for $\mathrm{PM}_{2.5}$ sensitivity to climate change, Atmos. Chem. Phys., 12, 3131-3145, doi:10.5194/acp12-3131-2012, 2012a.

Tai, A. P. K., Mickley, L. J., and Jacob, D. J.: Impact of 2000-2050 climate change on fine particulate matter $\left(\mathrm{PM}_{2.5}\right)$ air quality inferred from a multi-model analysis of meteorological modes, Atmos. Chem. Phys., 12, 11329-11337, doi:10.5194/acp-1211329-2012, 2012b.

Unger, N., Shindell, D. T., Koch, D. M., Amann, M., Cofala, J., and Streets, D. G.: Influences of man-made emissions and climate changes on tropospheric ozone, methane, and sulfate at 2030 from a broad range of possible futures, J. Geophys. Res., 111, D12313, doi:10.1029/2005JD006518, 2006.

van der Werf, G. R., Randerson, J. T., Giglio, L., Collatz, G. J., Kasibhatla, P. S., and Arellano Jr., A. F.: Interannual variability in global biomass burning emissions from 1997 to 2004, Atmos. Chem. Phys., 6, 3423-3441, doi:10.5194/acp-6-3423-2006, 2006.

van Donkelaar, A., Martin, R. V., and Park, R. J.: Estimating ground-level $\mathrm{PM}_{2.5}$ using aerosol optical depth determined from satellite remote sensing, J. Geophys. Res., 111, D21201, doi:10.1029/2005JD006996, 2006.

van Donkelaar, A., Martin, R. V., Park, R. J., Heald, C. L., Fu, T. M., Liao, H., and Guenther, A.: Model evidence for a significant source of secondary organic aerosol from isoprene, Atmos. Environ., 41, 1267-1274, doi:10.1016/j.atmosenv.2006.09.051, 2007. van Donkelaar, A., Martin, R. V., Leaitch, W. R., Macdonald, A. M., Walker, T. W., Streets, D. G., Zhang, Q., Dunlea, E. J., Jimenez, J. L., Dibb, J. E., Huey, L. G., Weber, R., and Andreae, M. O.: Analysis of aircraft and satellite measurements from the Intercontinental Chemical Transport Experiment (INTEX-B) to quantify long-range transport of East Asian sulfur to Canada, Atmos. Chem. Phys., 8, 2999-3014, doi:10.5194/acp-8-2999-2008, 2008.

Vestreng, V., Myhre, G., Fagerli, H., Reis, S., and Tarrasón, L.: Twenty-five years of continuous sulphur dioxide emission reduction in Europe, Atmos. Chem. Phys., 7, 3663-3681, doi:10.5194/acp-7-3663-2007, 2007.

Wallace, J. M. and Gutzler, D. S.: Teleconnections in the Geopotential Height Field during the Northern Hemisphere Winter, Mon. Weather Rev., 109, 784-812, doi:10.1175/15200493(1981)109<0784:TITGHF>2.0.CO;2, 1981.

Wang, H., Chen, H., and Liu, J.: Arctic Sea Ice Decline Intensified Haze Pollution in Eastern China, Atmospheric Oceanic Science Letters, 8, 1-9, doi:10.3878/AOSL20140081, 2015.

Wang, Y., Logan, J. A., and Jacob, D. J.: Global simulation of tropospheric $\mathrm{O}_{3}-\mathrm{NO}_{x}$-hydrocarbon chemistry: 2. Model evaluation and global ozone budget, J. Geophys. Res., 103, 10727, doi:10.1029/98JD00157, 1998.

Wesely, M. L.: Parameterization of surface resistances to gaseous dry deposition in regional-scale numerical models, Atmos. Environ., 23, 1293-1304, doi:10.1016/0004-6981(89)90153-4, 1989.

Wheeler, M. C. and Hendon, H. H.: An all-season real-time multivariate MJO index: Development of an index for monitoring and prediction, Mon. Weather Rev., 132, 1917-1932, doi:10.1175/1520-0493(2004)132<1917:AARMMI>2.0.CO;2, 2004.

Wise, E. K. and Comrie, A. C.: Meteorologically adjusted urban air quality trends in the Southwestern United States, Atmos. Environ., 39, 2969-2980, doi:10.1016/j.atmosenv.2005.01.024, 2005.

Wise, E. K., Wrzesien, M. L., Dannenberg, M. P., and McGinnis, D. L.: Cool-Season Precipitation Patterns Associated with Teleconnection Interactions in the United States, J. Appl. Meteorol. Clim., 54, 494-505, doi:10.1175/JAMC-D-14-0040.1, 2015.

Wu, S., Mickley, L. J., Jacob, D. J., Logan, J. A., Yantosca, R. M., and Rind, D.: Why are there large differences between models in global budgets of tropospheric ozone?, J. Geophys. Res., 112, D05302, doi:10.1029/2006JD007801, 2007.

Xiao, D., Li, Y., Fan, S., Zhang, R., Sun, J., and Wang, Y.: Plausible influence of Atlantic Ocean SST anomalies on winter haze in China, Theor. Appl. Climatol., 122, 249-257, doi:10.1007/s00704-014-1297-6, 2014.

Yang, Y., Liao, H., and Lou, S.: Decadal trend and interannual variation of outflow of aerosols from East Asia: Roles of variations in meteorological parameters and emissions, Atmos. Environ., 100, 141-153, doi:10.1016/j.atmosenv.2014.11.004, 2015.

Yienger, J. J. and Levy, H.: Empirical model of global soilbiogenic $\mathrm{NO}_{x}$ emissions, J. Geophys. Res., 100, 11447, doi:10.1029/95JD00370, 1995.

Zhang, L., Jacob, D. J., Knipping, E. M., Kumar, N., Munger, J. W., Carouge, C. C., van Donkelaar, A., Wang, Y. X., and Chen, D.: Nitrogen deposition to the United States: distribution, 
sources, and processes, Atmos. Chem. Phys., 12, 4539-4554, doi:10.5194/acp-12-4539-2012, 2012.

Zhang, L., Kok, J. F., Henze, D. K., Li, Q., and Zhao, C.: Improving simulations of fine dust surface concentrations over the western United States by optimizing the particle size distribution, Geophys. Res. Lett., 40, 3270-3275, doi:10.1002/grl.50591, 2013.

Zhang, G. J. and McFarlane, N. A.: Sensitivity of climate simulations to the parameterization of cumulus convection in the Canadian climate centre general circulation model, Atmos. Ocean, 33, 407-446, doi:10.1080/07055900.1995.9649539, 1995.
Zhou, Z.-Q., Xie, S.-P., Zheng, X.-T., Liu, Q., and Wang, H.: Global Warming-Induced Changes in El Niño Teleconnections over the North Pacific and North America, J. Climate, 27, 9050-9064, doi:10.1175/JCLI-D-14-00254.1, 2014.

Zhu, J., Liao, H., and Li, J.: Increases in aerosol concentrations over eastern China due to the decadal-scale weakening of the East Asian summer monsoon, Geophys. Res. Lett., 39, L09809, doi:10.1029/2012GL051428, 2012. 